\title{
Sağlık Çalışanlarının Yıldırıcı Davranışa Maruz Kalma ve Mesleki Adanmışılı Düzeylerinin Araştırılması: Bir Hastane Örneği ${ }^{1}$
}

\author{
Ayşe ÇETIN ${ }^{1}(\mathbb{D})$, Belma KEKLIK ${ }^{2 *}$ \\ ${ }^{1}$ Exp. Physiotherapist, Süleyman Demirel University Hospital, Department of Physical Therapy and \\ Rehabilitation, Isparta, Turkey \\ ${ }^{2}$ Prof. Dr., Süleyman Demirel University, Faculty of Economics and Administrative Sciences, Department of \\ Health Management, Isparta, Turkey
}

Geliş Tarihi/Received: 18.06.2020

Kabul Tarihi/Accepted: 12.08.2020

Araştırma Makalesi/Research Article

\section{ÖZET}

Sağlık kurumunun başarısı, tüm sağlı çalışanlarının gösterdiği çabayla büyük oranda alakalıdır. Sağlık hizmeti sunumunda hekim ve hemşire dışı diğer sağlık çalışanlarından, tanımlanmış görevlerini yerine getirmelerine ek olarak adanmışlıklarıyla kuruma katkı sağlamaları beklenmektedir. Bu nedenle son yıllarda sağlık çalışanlarının mesleki adanmışlık düzeylerini inceleyen çalışmalara olan ihtiyacın arttığı görülmektedir. Araştırmanın amacı, sağlık çalışanlarının yıldırıcı davranışa maruz kalma ve mesleki adanmışlık düzeylerini tespit ederek aralarındaki ilişkiyi ortaya koymaktır. Araştırmada Isparta İlinde bulunan bir kamu hastanesinde görev yapan hekim ve hemşire dışı toplam 104 sağlık çalışanı ile anket gerçekleştirilmiştir. Verilerin değerlendirilmesinde frekans analizleri, faktör analizi, regresyon analizi ve korelasyon analizi kullanılmıştır. Sonuçlar incelendiğinde yıldırıcı davranış faktörleri ile mesleki adanmışlık faktörleri arasında yapılan karşılaştırmada sadece "iş ve yaşam kalitesine yönelik saldırı" ile "gayret gösterme" arasında pozitif bir ilişki olduğu görülmüştür. "Mesleki itibara yönelik saldırı ve kendini göstermenin engellenmesi" yıldırıcı davranışının "mesleği sevme" üzerinde istatistiksel olarak anlamlı ve negatif yönlü bir etkisinin olduğu tespit edilmiştir.

\footnotetext{
${ }^{1} \mathrm{Bu}$ çalışma, danışmanlığı Belma Keklik tarafından yürütülen Ayşe Çetin'in "Sağlık Çalışanlarının Yıldırıcı Davranışa Maruz Kalma(Mobbing) ve Mesleki Adanmışlık Düzeylerinin Araştırılması: Bir Araștırma ve Uygulama Hastanesi Örneği” başlıklı yüksek lisans tezinden üretilmiştir. Bu çalışmaya ilişkin Süleyman Demirel Üniversitesi, Sosyal ve Beşeri Bilimler Etik Kurulunun 09.04.2015 tarihli, 12 sayılı toplantı ve 4 sayılı kararı ile etik kurul onayı bulunmaktadır.
}

* Sorumlu yazar/Corresponding author

E-mail/e-ileti: belmakeklik@sdu.edu.tr 
Çetin, A. \& Keklik, B.

Anahtar kelimeler: Yıldırıcı Davranış, Mesleki Adanmışlık, Sağlık Çalışanı.

\title{
A Research on Psychological Violence Behaviors and Levels of Job Commitment of Healthcare Employees: A Case Study of a Hospital
}

\begin{abstract}
The success of a health institution is mostly related to efforts of its health care workers. In order to achieve health service delivery goals of the institution, other health care workers are expected to both fulfill their determined tasks and job commitments contribute to their organizations. Considering this critical aspects, it has been lately determined a necessity of scholarly work on scrutinizing health care workers' job commitments. This study aims to examine the relationship between psychological violence (mobbing) behaviors and levels of job commitment of healthcare employees. Using quantitative methodology, except for doctors and nurses, a survey conducted with 104 health care workers who had been serving in a University Hospital. In the evaluation of the datum, it is drawn upon, frequency analysis, factor analysis, regression and correlation analysis are used. As a result of analyzes performed to determine the relationship between psychological violence and job commitment, there is a positive relationship between "quality of work and life" and "effort". Also it is found that there is a significant negative relationship between "violance to job reputation and obstruction to selfesteem" and "love to job".
\end{abstract}

Keywords: Psychological Violence, Mobbing Behavior, Job Commitment, Health Care Worker.

\section{GíRiş}

Günümüzde çalışma yaşamının önemli bir gerçeği olan yıldırıcı davranış, her geçen gün iş yaşamında artarak yaşanmaya devam etmektedir. İşyerindeki çalışma koşullarıyla yakından ilişkili olan yıldırıcı davranış olayları, küresel boyutta yaygın bir sorun olarak kabul edilmekte ve araştırmacıların da konuya ilgilerinin artmasına neden olmaktadır.

Yıldırıcı davranışın gerek birey açısından (mağdurun fizyolojik ve psikolojik sağlık durumunun olumsuz etkilenmesi, hayat kalitesinin düşmesi, sosyal ilişkilerinde bozulma, işsiz kalma ve akabinde ekonomik zorluklar gibi) gerekse organizasyon açısından (çalışanların stres düzeylerinin artması, devamsızlık, verimliliğin düşmesi, iş kalitesinde ve çalışanın işe olan ilgisinde azalma vb.) önemli sayılabilecek çeşitli sonuçları olduğu bilinmektedir. 
Hastaneler sağlık çalışanları için gün geçtikçe tehlikeli ortamlar olmaktadır. Bu durumda sağlık çalışanları kendilerini güvende hissetmemektedir. Gerek sağlık hizmetindeki hızlı değişimler gerek yasal uygulamalardaki eksiklikler şiddetin önlenmesinde ve sağlık insan gücünün güvenliğini sağlama konusunda boşluklar bırakmaktadır (Annagür, 2010: 161-173). Yıldırıcı davranışlar, hastanelerde yaygın olarak görülen ve çalışanlar için tedbir alınmasını gerektiren düzeyde ciddi bir mesleki sağlık ve güvenlik riskidir. İşyerlerinde gerek yönetim, gerekse çalışanlar bakımından alınacak tedbirler ve yapılacak düzenlemeler için, bu sorunun farkındalığının sağlanması oldukça önemlidir (Arısoy, 2011: 143). Sağlık çalışanlarının maruz kaldığı yıldırıcı davranışa ilişkin yurt dışı ve yurt içinde birçok çalışma yapılmıştır. Çalışmalardan elde edilen bulguların ortak noktası; sağlık alanında ortaya çıkan yıldırıcı davranışın diğer işyerlerine göre oldukça fazla olduğu ve daha az kayda alındığıdır. Sağlık kurumlarındaki yıldırıcı davranışın az oranda bildirildiği, sadece yaralanma gibi ciddi olayların şiddet olarak algılandığı, diğerlerinin bildirilmediği çalışmalar da öne çıkmıştır (Özcan, 2011: 1454) Kamu hizmeti veren kuruluşlar arasında, yoğun iş yükü, düzensiz ve belirsiz çalışma koşulları ile sağlı hizmeti veren işyerlerinde yıldırıcı davranış daha çok görülmektedir (Dahlberg vd., 2002: 3). Sağlık çalışanlarının yıldırıcı davranışa uğrama riskinin diğer sektörlerde çalışanlara oranla 16 kat daha fazla olduğu belirtilmektedir (Kingma, 2001: 129). Sağlık kurumlarında yıldırıcı davranış; hasta, hasta yakınları ya da diğer başka bir bireyden gelen, sağlık çalışanı için risk oluşturan sözel ya da davranışsal tehdit, fiziksel veya cinsel saldırıdır (Saines, 1999: 9).

Yoğun çalışma temposu, uzun süreli ve kesintisiz çalışma, ergonomik olmayan çalışma ortamları ve iş gerilimi sağlık çalışanlarının diğer iş kollarında çalışanlara göre çok daha çeşitli mesleki risklerle karşılaşmasına ve sağlıklarının olumsuz etkilenmesine yol açmaktadır. Bunların yanı sıra çalışma ortamında kişiler arasındaki ilişkiler önem taşımaktadır (Yiğitbaş ve Deveci, 2011: 23).

Sağlık hizmeti günümüzde eski dönemlerde olduğu gibi yalnızca hekim ve hemşire ile verilebilecek bir hizmet olmaktan uzaklaşmıştır. Diğer sağlık meslek çalışanlarının (biyolog, fizyoterapist, odyolog, diyetisyen, sağlık teknikeri vs.) hekim ve hemşirelerle birlikte ve dayanışma içinde çalışmak zorundadır. Çünkü sağlık hizmetleri sunumu bir ekip çalışmasını gerektirmektedir.

Geçmişte yıldırıcı davranış ve mesleki adanmışlık üzerine yapılan araştırmaların genellikle hekim ve hemşire odaklı olduğu görülmüştür. Sağlık hizmeti sunumunda diğer sağlık 
çalışanlarını ele alan çalışmaların azlığı dikkati çekmektedir. Bu çalışmada söz konusu eksikliğin giderilmesine yönelik diğer sağlık çalışanlarının yıldırıcı davranışa maruz kalma ile mesleki adanmışlıkları düzeyleri belirlenmeye çalışılmış ve arasındaki ilişki araştırılmıştır. Örneklem olarak Isparta il merkezinde bulunan bir kamu hastanesinde görev yapan hekim ve hemşire dışı sağlık çalışanları üzerinde araştırma yapılmış ve çeşitli bulgular elde edilmiştir.

\section{ARAŞTIRMANIN AMACI VE ÖNEMI}

Araştırmanın üç amacı bulunmaktadır. İlki, hekim ve hemşire dışı sağlık çalışanlarının yıldırıcı davranışa maruz kalma ve mesleki adanmışlık düzeylerinin belirlenmesi, ikincisi söz konusu düzeyler arasındaki ilişkinin ortaya konulması, üçüncü amacı ise yıldırıcı davranışların mesleki adanmışlık üzerine etkisinin araştırılmasıdır.

Sağlık sektöründe ve diğer sektörlerde yıldırıcı davranış ile mesleki adanmışlığı birlikte ele alan çalışmaların sayıca az olduğu görülmektedir. Yapılan çalışmaların büyük bir kısmı sadece yıldırıcı davranışa veya sadece mesleki adanmışlığa yönelik iken bazıları ise yıldırıcı davranış ile örgütsel adanmışlı̆̆ı birlikte ele almıştır. Yerli yazında yapılan araştırmalar sonucunda hekim ve hemşire dışı sağlık çalışanlarına yönelik yıldırıcı davranış ile mesleki adanmışlık ilişkisinin bir arada incelendiği bir çalışmaya rastlanmamıştır. Bu bakımdan çalışmanın literatüre katkı sağlayacağı düşünülmektedir. Çalışmada, hekim ve hemşire dışı sağlık çalışanlarına yönelik yapılan anketlerden elde edilen verilerin analizlerinden ortaya çıkan bulguların, hastane yönetimi için yararlı bilgiler oluşturacağı düşünülmektedir. Yöneticiler, çalışanlarının yıldırıcı davranışa maruz kalma ve mesleki adanmışlık düzeyleri hakkında bilgi edinerek, kurumda yıldırıcı davranışların engellenmesine yönelik tedbirler almaları ve mesleki adanmışlığı arttıracak faktörler hakkında fikir edinebilmeleri bakımından önem taşımaktadır.

\section{ARAŞTIRMANIN YÖNTEMI}

\subsection{Araştırmanın Kısıtları ve Varsayımları}

Bu araştırmaya yönelik ilk olarak Süleyman Demirel Üniversitesi, Sosyal ve Beşeri Bilimler Etik Kurulunun 09.04.2015 tarihli, 12 sayılı toplantı ve 4 sayılı kararı ile etik kurul onayı alınmıştır. Araştırma kapsamındaki hastanede görev yapan hekim ve hemşire dışı 104 sağlık personelinin (röntgen teknisyeni, laborant, biyolog, fizyoterapist, diyetisyen, sağlık teknisyeni ve sağlık memuru, psikolog, eczacı, odyolog, acil tıp teknisyeni, fizyoterapi teknisyeni, sosyal çalışmacı, anestezi teknisyeni) bilgi toplama aracı olarak anket sorularına verdikleri cevaplar, onların gerçek görüş ve düşüncelerine dayandığı ve seçilen evreni temsil 
ettiği varsayılmıştır. Araştırma Isparta il merkezinde hizmet veren kamu sektörüne ait bir hastanedeki sağlık çalışanlarını kapsadığı için sonuçlar bu örneklemin özelliklerini yansitmaktadir.

\subsection{Evren ve Örneklem}

Araştırmanın evrenini Isparta'da bir kamu hastanesinde çalışan hekim ve hemşire dışı sağlık çalışanları oluşturmaktadır. Hekimler ve hemşirelere yönelik yıldırıcı davranış veya mesleki adanmışlık konusu üzerine geçmişte çalışmaların var olması nedeniyle bu çalışmaya söz konusu kesim dahil edilmemiştir. Anket çalışmasına başlamadan önce ilgili kurumdan gerekli izinler alınmış ve anket çalışması araştırmacının kendisi tarafından yapılmıştır. Anket ile ilgili bazı bilgiler uygulayıcılara açıklanmış ve bu çalışmanın gönüllülük esasına dayalı olduğu belirtilmiştir. Anketler uygulayıcılara teker teker dağıtılmıştır. Anketlerin büyük bir kısmı hemen toplanmış kalan kısmı için ise uygulayıcıların uygun gördüğü zamanlarda tamamlanmıştır.

Kurumdan alınan veriler 1şığında hekim ve hemşire dışı 132 sağlık çalışanı olduğu tespit edilmiştir. Araştırma kapsamında bütün sağlık çalışanlarına ulaşılarak anket uygulanmak istenmiş fakat görevlendirmeler, çalışma yoğunluğu, izinler, anket formunun cevaplanmak istenmemesi ve dağıtılan anket formu kayıpları gibi sebeplerden dolayı sağlık çalışanlarına 120 anket formu dağıtılmıştır. Dağıtılan anket formlarının 104'ü geri dönmüştür. Anket formları incelemeye alınmış, eksik ve hatalı doldurulan hiç bir formun bulunmadığı görüldüğünden 104 anket formu analiz kapsamına alınmıştır.

Örneklem büyüklüğü aşağıdaki formül kullanılarak belirlenmektedir.

$$
\mathrm{n}=\left(\mathrm{N} \mathrm{t} \mathrm{t}^{2} \mathrm{p} \mathrm{q}\right) /\left(\mathrm{d}^{2}(\mathrm{~N}-1)+\mathrm{t}^{2} \mathrm{p} \mathrm{q}\right)
$$

n: Örneklem büyüklüğü

$\mathrm{N}$ : Anakütle büyüklüğü

t: $(\alpha, s d): \alpha$ anlamlılık düzeyinde, serbestlik derecesine göre $\mathrm{t}$ tablosu kritik değeri

p: İlgilenilen olayın görülme olasılı̆̆ı

q: 1-p (veya ilgilenilen olayın görülmeme olasılığı) 
d: kabul edilen \pm örnekleme hata oranı

Ana kütle: 132, Güven düzeyi: \%95, Güven aralığı: \%5'dir. Buna göre gerekli örneklem büyüklüğü (n) : 99’dur.

Böylece araştırmaya konu olarak alınan kamu hastanesindeki 104 sağlık çalışanı bu araştırmanın örneklem grubunu oluşturmaktadır.

\subsection{Veri Toplama Aracı}

Araştırmada veri toplama aracı olarak Yıldırıcı Davranış ve Mesleki Adanmışlık anketi kullanılmıştır. Veriler Haziran-Temmuz 2015 tarihinde elde edilmiştir. Anket demografik soruların bulunduğu bölüm ile birlikte toplam 60 ifadeden oluşmaktadır. Anket formu üç bölümden oluşmakta ve birinci bölümde cinsiyet, yaş, medeni durum, eğitim durumu, meslek, kurumdaki kıdem süresi ve toplam mesleki tecrübe süresi gibi çalışanların sosyo-demografik özelliklerini belirleyici sorular bulunmaktadır.

İkinci bölümde yıldırıcı davranışa maruz kalma düzeyini belirlemek amacıyla Yıldırım ve Yıldırım (2007) tarafından geliştirilmiş olan "İş Yerinde Psikolojik Şiddet Davranışları Ölçme ve Geliştirme” anketi kullanılmıştır. Bu ölçekte yıldırıcı davranışın "Mesleki İtibara Yönelik Saldırı ve Kendini Göstermenin Engellenmesi” boyutunu ölçmeye yönelik 8 soru (10., 11., 12., 13., 14., 16., 17., 27. sorular), "Kişisel İtibara Yönelik Saldırı” boyutunu ölçmek için 6 soru (1., 2., 3., 4., 9., 15. sorular), "İ̧s ve Yaşam Kalitesine Yönelik Saldırı” boyutunu ölçmek için 4 soru (7., 28., 29., 30. sorular), "Sosyal İlişskilere Yönelik Saldırı” boyutunu ölçmek için 4 soru (19., 20., 21., 22. sorular), "İletişime Yönelik Saldırı" boyutunu ölçmek için 4 soru (23., 24., 25., 26. sorular) bulunmaktadir.

Ankette yıldırıcı davranışa maruz kalma düzeyini belirlemek için 5 puanlı Likert tipi cevaplama sistemi kullanılmıştır. Yıldırıcı davranış ölçeğine ait ifadeler için (1) puanı "Hiç Karşılaşmadım”, (2) puanı "Bir kaç kez karşılaştım”, (3) puanı "Bazen Karşılaşırım”, (4) puanı “Sık Sık Karşılaşırım”, (5) puanı "Her Zaman Karşılaşırım”şeklinde derecelendirilmiştir.

Üçüncü bölümde ise, mesleki adanmışlık düzeyinin belirlenmesi amacıyla Turhan vd. (2012)'nin literatür taraması sonucu elde ettikleri bilgiler etrafında 22 maddeden oluşan "Sınıf Öğretmenlerinin Mesleğe Adanmışlık Düzeyi” anket formu kullanılmıştır. Ölçeğin 4., 5., 10., 13., 21. sorularını "Mesleği Sevme", 7., 8., 11., 12. sorularını "Haz Alma”, 18., 19., 20., 22. sorularını "Değer Verme", 3., 14., 15. soruların1 "Gayret Gösterme", 9., 17. soruların1 
“Zorlanma" boyutu oluşturmaktadır. Ankette mesleki adanmışlık düzeyini belirlemek için 5 puanlı Likert tipi cevaplama sistemi kullanılmıştır. Buna göre ankete katılanlar; (1) Hiç Katılmiyorum, (2) Nadiren Katılıyorum, (3) Bazen Katılıyorum, (4) S1k S1k Katıliyorum, (5) Her Zaman Katılıyorum şeklindeki ifadelerden birisini seçerek yargılarını belirtmişlerdir.

\subsection{Analiz Yöntemi}

Anket formları aracılığıyla elde edilen veriler SPSS 22.0 (Statistical Package for Social Sciences) programı kullanılarak bilgisayar ortamına aktarılmış ve verilerin incelenmesinde bu programdan faydalanılmıştır. Yapılan analizlerde sırasıyla;

- Yıldırıcı davranış ve mesleki adanmışlık ölçeklerinin güvenirlik vegeçerlilikleri sağlanmıştır.

- Ankette yer alan yıldırıcı davranış ve mesleki adanmışlık boyutları içerisindeki ifadelerin aritmetik ortalamaları ve standart sapmaları hesaplanmıştır.

- Yıldırıcı davranış ve mesleki adanmışlık boyutları arasındaki ilişkinin ortaya konulabilmesi için Pearson korelasyon analizi yapılmıştır.

- Yıldırıcı davranışın mesleki adanmışlığa etkisini ortaya çıkarabilmek için de çoklu regresyon analizleri yapılmıştır.

\subsection{Hipotezler}

$\mathrm{Bu}$ araştırmanın teorik bölümünde ele alınan konular doğrultusunda ve çalışmanın amacına bağlı aşağıdaki hipotezler oluşturulmuştur.

A. Sağlık çalışanlarının yıldırıcı davranışa maruz kalmaları ile

A1: Mesleki İtibara Yönelik Saldırı ve Kendini Göstermenin Engellenmesi

A2: Kişisel İtibara Yönelik Saldırı

A3: Sosyal İlişkilere Yönelik Saldırı

A4: İletişime Yönelik Saldırı

A5: İş ve Yaşam Kalitesine Yönelik Saldırı

arasında bir ilişki vardır. 
Çetin, A. \& Keklik, B.

B. Mesleki Adanmışlık düzeyleri ile

B1: Meslĕgi Sevme

B2: Haz Alma

B3: Meslĕ̆e Dĕger Verme

B4: Gayret Gösterme

B5: Zorlanma

arasında bir ilişki vardır.

\subsection{Araştırma Modeli}

Araştırma modeli Şekil 1'de gösterilmektedir.

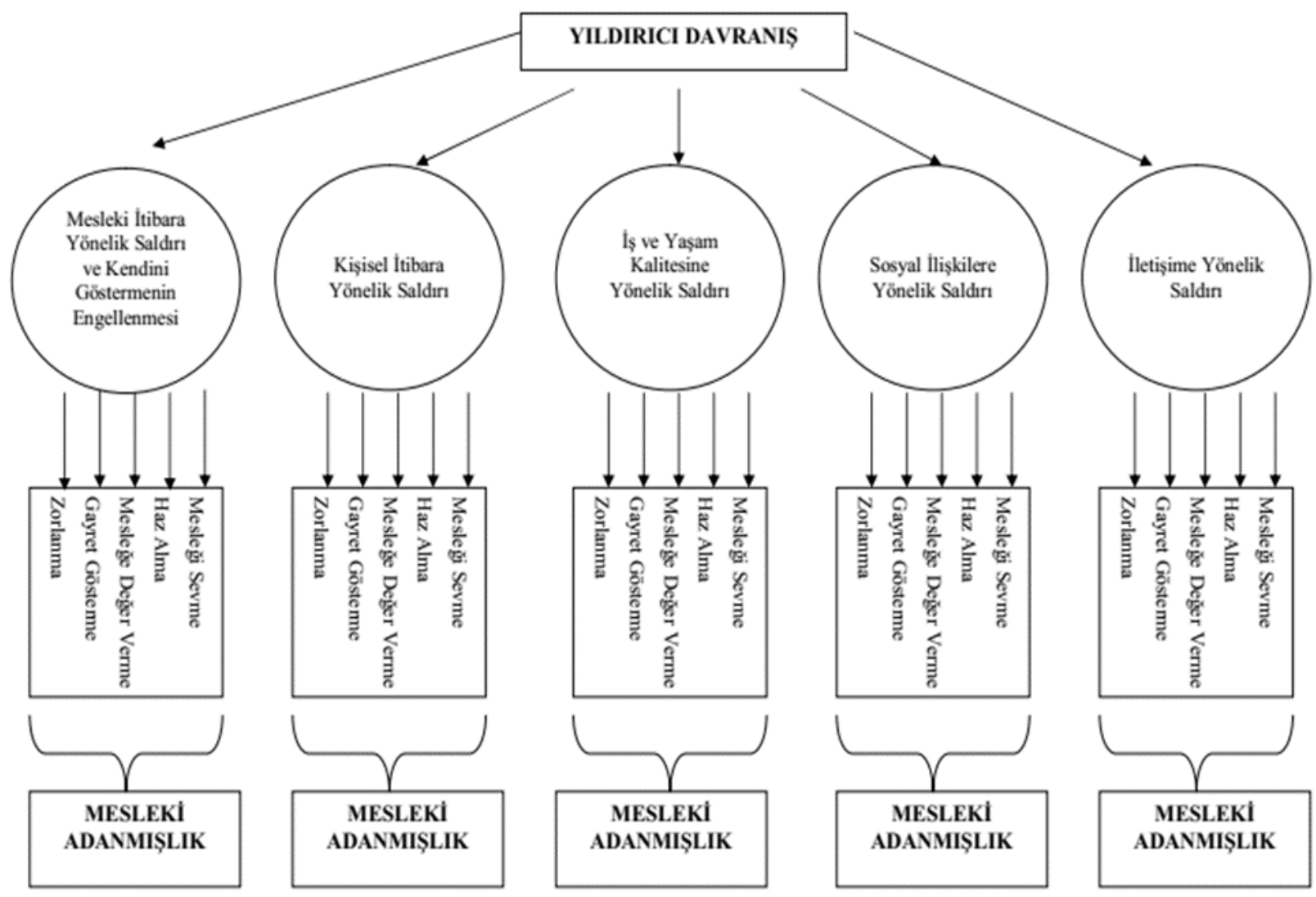

Şekil 1. Araştırma modeli

\section{GÜVENIRLIK VE GEÇERLIKK ANALIZZLERI}


Çalışmada kullanılan 2 ayrı ölçeğin (yıldırıcı davranış ölçeği ve mesleki adanmışlık ölçeği) geçerlik ve güvenirlik analizlerine yer verilmiştir. Faktör analizi ile elde edilen verilere dayanarak her bir ölçeğin alt boyutlarının güvenirlik katsayıları da hesaplanmıştır.

\subsection{Yıldırıcı Davranış Ölçeğinin Güvenilirlik ve Geçerlilik Analizleri}

Yıldırıcı davranış ölçeğinin geçerlilik ve güvenilirlik çalışması Yıldırım ve Yıldırım (2005) tarafından yapılmış ve Cronbach Alpha değeri 0,930 olarak bulunmuştur. Bu çalışmada ise Cronbach Alpha değeri 0,968 olarak hesaplanmıştır. Cronbach Alpha değerinin $0.80 \leq \alpha<1.00$ olmasından dolayı ölçeğin yüksek güvenilirlikte olduğu söylenebilir (Özdamar, 2004: 36).

Tablo 1. Yıldırıcı davranış ölçeği boyutlarının güvenilirlik katsayıları

\begin{tabular}{|c|c|c|}
\hline Boyutlar & $\begin{array}{c}\begin{array}{c}\text { Cronbach Alpha } \\
\text { Katsayıları }\end{array} \\
\end{array}$ & Madde Numaraları \\
\hline $\begin{array}{l}\text { Mesleki İtibara Yönelik Saldırı ve Kendini } \\
\text { Göstermenin Engellenmesi }\end{array}$ & 0,940 & $10,11,12,13,14,16,17,27$ \\
\hline Kişisel İtibara Yönelik Saldırı & 0,879 & $1,2,3,4,9,15$ \\
\hline İş ve Yaşam Kalitesine Yönelik Saldırı & 0,848 & $7,28,29,30$ \\
\hline Sosyal İlişkilere Yönelik Saldırı & 0,830 & $19,20,21,22$ \\
\hline İletişime Yönelik Saldırı & 0,878 & $23,24,25,26$ \\
\hline Yıldırıcı Davranış Ölçeği Genel Sonuç & 0,968 & $\begin{array}{r}1,2,3,4,7,9,10,11,12,13,14 \\
15,16,17,19,20,21,22,23,24 \\
25,26,27,28,29,30\end{array}$ \\
\hline
\end{tabular}

Yı1dırıcı davranış ölçeğinin yapı geçerliliğini ölçmek amacıyla faktör analizi kullanılmıştır. Faktör analizi sonucunda oluşan 5 faktör toplam varyansın \%74.190'ını açıklamaktadır. İyi bir faktörleşme yapısı elde etmek için varimax dönüşüm yöntemi kullanılmıştır. Elde edilen faktör analizi sonuçları Tablo 2'de gösterilmiştir.

Tablo 2. Yıldırıcı davranış ölçeğinin faktör analizi sonuçları 


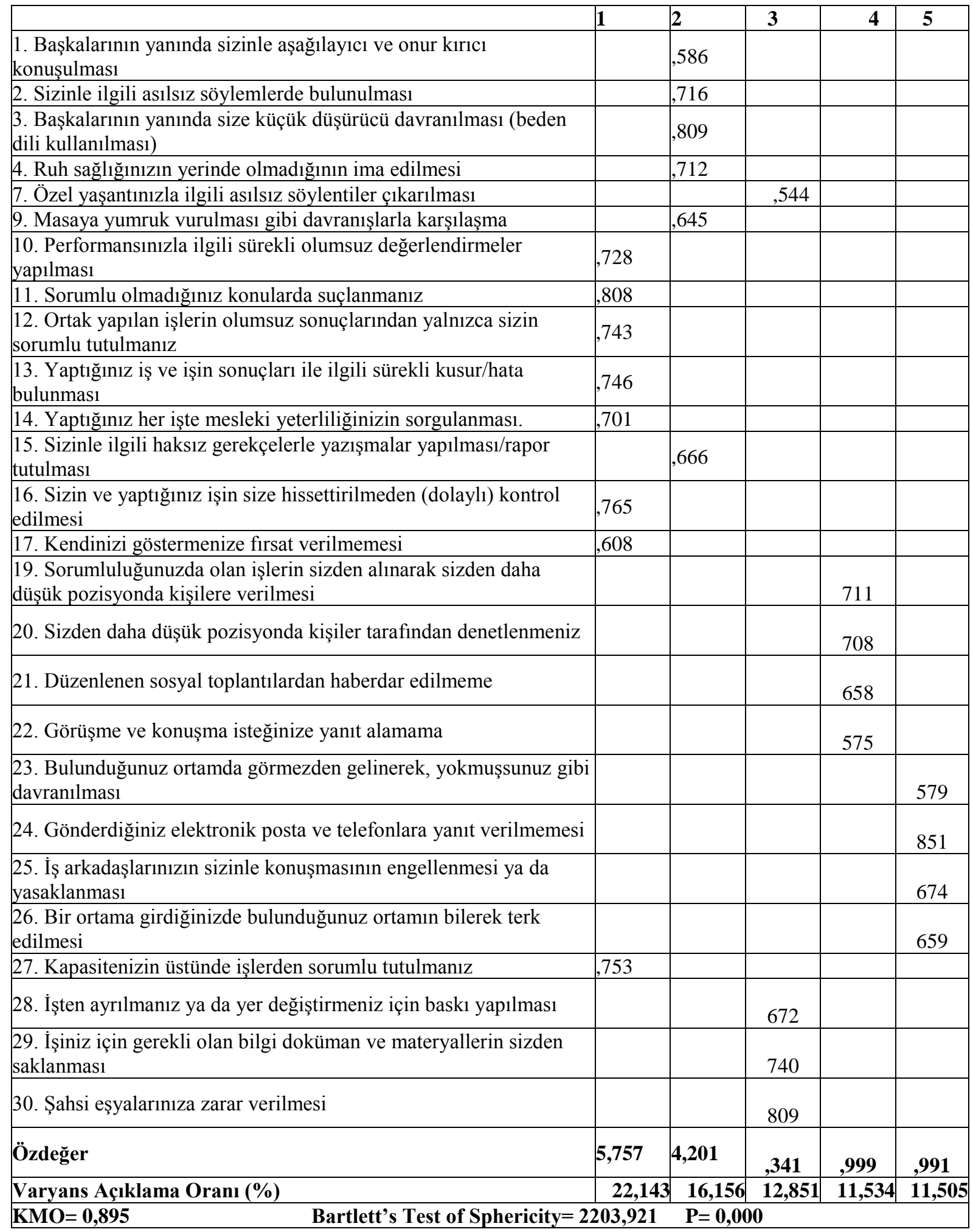

Faktör analizinde KMO oranının $(0,5)$ 'nin üzerinde olması gerekir. Oran ne kadar yüksek olursa veri seti faktör analizi yapmak için o kadar iyidir denilebilir (Kalaycı, 2006: 322). KMO değeri 0,895 (mükemmel) çıktığından, mevcut örneklem büyüklüğünün faktör analizi yapabilmek için yeterli düzeyde olduğu ifade edilebilir. Bartlett küresellik testi ise değişkenler 
arasındaki korelasyonların yüksek düzeyde olduğunu göstermektedir. Bartlett küresellik testinde $\mathrm{P} \leq 0,05$ olması gerekir (Şencan, 2005: 384). Bartlett değeri $\leq 0,05$ çıktığı için veriler faktör analizine uygundur.

Tablo 2'de görüldüğü gibi faktör yükleri 0,50’nin üstündedir. Anket soruları beklendiği gibi 5 faktör altında toplanmıştır. Ancak ankette yer alan 5, 6, 8, 18 ve 31. maddeler faktör analizine uymadığı için analiz dışı bırakılmıştır. Bu durumda ölçeğin yap1 geçerliliğinin sağlandığ 1 ifade edilebilir.

\subsection{Mesleki Adanmışlık Ölçeğinin Güvenilirlik ve Geçerlilik Analizleri}

Mesleki adanmışlık ölçeğinin geçerlilik ve güvenilirlik çalışması Turhan vd. (2012) tarafından yapılmış ve Cronbach Alpha değeri 0,791 olarak bulunmuştur. Bu çalışmada ise Cronbach Alpha değeri 0,630 olarak hesaplanmıştır. Cronbach Alpha değerinin $0.60 \leq \alpha<0.80$ olmasından dolayı ölçeğin oldukça güvenilir olduğu söylenebilir (Özdamar, 2004: 36).

Tablo 3. Mesleki adanmışlık ölçeği boyutlarının güvenilirlik katsayıları

\begin{tabular}{|c|c|c|}
\hline Boyutlar & $\begin{array}{c}\text { Cronbach Alpha } \\
\text { Katsayıları }\end{array}$ & Madde Numaraları \\
\hline Mesleği Sevme & 0,827 & $4,21,5,10,13$ \\
\hline Haz Alma & 0,723 & $7,11,8,12$ \\
\hline Mesleğe Değer Verme & 0,709 & $19,20,22,18$ \\
\hline Gayret Gösterme & 0,645 & $15,3,14$ \\
\hline Zorlanma & 0,627 & 9,17 \\
\hline $\begin{array}{l}\text { Mesleki Adanmışlık Ölçeği } \\
\text { Genel Sonuç }\end{array}$ & 0,630 & $\begin{array}{r}3,4,5,7,8,9,10,11,12,13,14 \\
15,17,18,19,20,21,22 \\
\end{array}$ \\
\hline
\end{tabular}

Alt boyutlar için alpha katsayıları "mesleği sevme" için 0,827, "mesleğe değer verme" için 0,723, "gayret gösterme" için 0,709, "haz alma" için 0,645, "zorlanma” için de 0,627 olarak bulunmuştur. Bu değerlere göre mesleki adanmışlık ölçeğinin oldukça güvenilir bir iç tutarlılığa sahip olduğu ve güvenirliğin sağlandığı görülmektedir.

Mesleki adanmışlık ölçeğinin yapı geçerliliğini ölçmek amacıyla faktör analizi kullanılmıştır. Faktör analizi sonucunda oluşan 5 faktör toplam varyansın \%63,834'ünü açıklamaktadır. İyi bir faktörleşme yapısı elde etmek için varimax dönüşüm yöntemi kullanılmıştır. Elde edilen faktör analizi sonuçları Tablo 4'de gösterilmiştir. 
Çetin, A. \& Keklik, B.

Tablo 4. Mesleki adanmışlık ölçeğinin faktör analizi sonuçları

\begin{tabular}{|c|c|c|c|c|c|}
\hline \multirow{2}{*}{ Maddeler } & \multicolumn{5}{|c|}{ Faktörler } \\
\hline & 1 & 2 & \begin{tabular}{l|l}
3 \\
\end{tabular} & 4 & 5 \\
\hline \begin{tabular}{|l|} 
4. Çocuğumun bir sağlık çalışanı \\
olmasını isterim
\end{tabular} & ,851 & & & & \\
\hline $\begin{array}{l}\text { 21. Yeniden dünyaya gelsem yine de } \\
\text { bu mesleği seçerim }\end{array}$ & ,843 & & & & \\
\hline 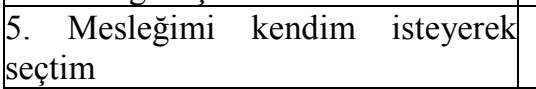 & ,689 & & & & \\
\hline $\begin{array}{l}\text { 10. En güzel mesleğin sağl1k mesleği } \\
\text { olduğunu düşünüyorum }\end{array}$ & ,635 & & & & \\
\hline $\begin{array}{l}\text { 13. Zaman geçtikçe mesleğimi daha } \\
\text { çok severek yapıyorum }\end{array}$ & ,592 & & & & \\
\hline $\begin{array}{l}\text { 7. Hasta insanlara yardım etmek için } \\
\text { bu mesleği (beyaz önlüğü) seçtim }\end{array}$ & & ,749 & & & \\
\hline $\begin{array}{l}\text { 11. İletişim becerimin daha iyi } \\
\text { olduğuna inandığım için bu mesleği } \\
\text { seçtim }\end{array}$ & & ,722 & & & \\
\hline 8. Sağlık mesleği zevkli bir meslektir & & ,660 & & & \\
\hline $\begin{array}{l}\text { 12. Hastaların daha iyi sağlık hizmeti } \\
\text { almalarında en önemli faktör sağlık } \\
\text { çalışanıdır }\end{array}$ & & ,538 & & & \\
\hline 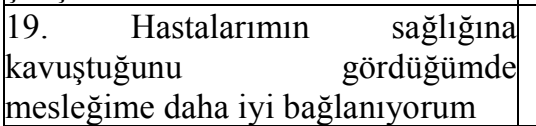 & & &, 771 & & \\
\hline $\begin{array}{l}\text { 22. Sağlık mesleğinin kutsal bir } \\
\text { meslek olduğunu düşünüyorum }\end{array}$ & & &, 737 & & \\
\hline $\begin{array}{|lrr|}20 . & \text { Bir insanın sağlı̆̆ına } \\
\text { kavuşmasında } & \text { sağlık mesleği önemli } \\
\text { bir meslektir } & & \\
\end{array}$ & & &, 712 & & \\
\hline $\begin{array}{l}\text { 18. Mesleğimi yaparken hasta ve } \\
\text { çalışan işbirliğini (ekip çalışmasını) } \\
\text { önemsiyorum }\end{array}$ & & &, 595 & & \\
\hline $\begin{array}{l}\text { 15. Mesleki alanında tecrübemi } \\
\text { artıracak faaliyetlere katıllyorum }\end{array}$ & & & &, 823 & \\
\hline $\begin{array}{l}\text { 3. Mesleğimle ilgili gelişmeleri takip } \\
\text { ediyorum }\end{array}$ & & & & ,727 & \\
\hline $\begin{array}{l}\text { 14. Sağlık mesleği alanında kendimi } \\
\text { yeterli buluyorum }\end{array}$ & & & & ,603 & \\
\hline $\begin{array}{l}\text { 17. Sağlık mesleği yıpratıcı bir } \\
\text { meslektir }\end{array}$ & & & & & ,773 \\
\hline \begin{tabular}{|llll} 
9. Sağlık mesleği yorucu bir \\
meslektir
\end{tabular} & & & & & ,766 \\
\hline Özdeğer & 3,234 & 2,370 & 2,241 & 1,890 & 1,754 \\
\hline Varyans Açıklama Oranı (\%) & 17,967 & 13,169 & 12,451 & \begin{tabular}{l|l}
10,501 \\
\end{tabular} & 9,746 \\
\hline $\mathrm{KMO}=0,716$ & lett's Test o & Sphericity $=6$ & 3,188 $\quad P=$ & 000 & \\
\hline
\end{tabular}

Faktör analizinde KMO değeri 0,716 (çok iyi) çıktığından, mevcut örneklem büyüklüğünün faktör analizi yapabilmek için yeterli düzeyde olduğu ifade edilebilir. Bartlett küresellik testi ise değişkenler arasındaki korelasyonların yüksek düzeyde olduğunu göstermektedir. Bartlett küresellik testinde $\mathrm{P} \leq 0,05$ olması gerekir (Şencan, 2005: 384). Bartlett değeri $\leq 0,05$ çıtı̆̆ 1 için veriler faktör analizine uygundur. 
Tablo 4'de görüldüğü gibi faktör yükleri 0,50’nin üstündedir. Anket soruları beklendiği gibi 5 faktör altında toplanmıştır. Ancak ankette yer alan 1, 2, 6 ve 16. maddeler faktör analizine uymadığı için analiz dışı bırakılmıştır. Bu durumda ölçeğin yapı geçerliliğinin sağlandığı ifade edilebilir.

\section{BULGULAR}

Çalışmanın bu bölümünde, kişisel bilgi formundan yola çıkarak örneklemi tanıtıcı frekans ve yüzde dağılımlarına, açıklamaları ile birlikte yer verilmiştir. Daha sonra yıldırıcı davranış ve mesleki adanmışlık ölçeklerinden elde edilen veriler araştırmanın amaçları doğrultusunda istatistiksel analizlere tabi tutulmuş ve bu analizler yorumlanmıştır.

\subsection{Kişisel Bilgi Formundan Elde Edilen Verilere Ait Bulgular}

Araştırma kapsamında sağlık çalışanlarının cinsiyet, yaş, medeni durum, eğitim, unvan, kurumdaki kıdem yılı ve toplam mesleki tecrübe süresi durumlarına ilişkin şu sonuçlara ulaşılmıştır. 
Çetin, A. \& Keklik, B.

Tablo 5. Hastane çalışanlarının bağımsız değişkenlere göre dağılımları

\begin{tabular}{|c|c|c|c|}
\hline Değişkenler & Gruplar & Frekans (n) & Yüzde (\%) \\
\hline \multirow{3}{*}{ Cinsiyet } & Kadin & 49 & 47.1 \\
\hline & Erkek & 55 & 52.9 \\
\hline & Toplam & 104 & 100 \\
\hline \multirow{5}{*}{ Yaş } & $25^{\prime}$ in alt1 & 18 & 17.3 \\
\hline & $25-29$ aras 1 & 10 & 9.6 \\
\hline & $30-34$ aras 1 & 20 & 19.2 \\
\hline & 35 ve üzeri & 56 & 53.8 \\
\hline & Toplam & 104 & 100 \\
\hline \multirow{3}{*}{ Medeni Durum } & Bekar & 29 & 27.9 \\
\hline & Evli & 75 & 72.1 \\
\hline & Toplam & 104 & 100 \\
\hline \multirow{5}{*}{ Eğitim Durumu } & Lise & 9 & 8.7 \\
\hline & Ön Lisans & 47 & 45.2 \\
\hline & Lisans & 32 & 30.8 \\
\hline & Lisansüstü & 16 & 15.4 \\
\hline & Toplam & 104 & 100 \\
\hline \multirow{14}{*}{ Unvan } & Röntgen Tekn. & 26 & 25.0 \\
\hline & Laborant & 6 & 5.8 \\
\hline & Biyolog & 18 & 17.3 \\
\hline & Fizyoterapist & 5 & 4.8 \\
\hline & Diyetisyen & 4 & 3.8 \\
\hline & Sağlık Tekn. ve Sağlık Memuru & 30 & 29.8 \\
\hline & Psikolog & 1 & 1.0 \\
\hline & Eczaci & 2 & 1.9 \\
\hline & Odyoloji & 1 & 1.0 \\
\hline & Acil Tip Tekn. & 1 & 1.0 \\
\hline & Fizyoterapi Tekn. & 3 & 2.9 \\
\hline & Sosyal Çalışmacı & 1 & 1.0 \\
\hline & Anestezi Tekn. & 6 & 5.8 \\
\hline & Toplam & 104 & 100 \\
\hline \multirow{5}{*}{ Kıdem Süresi } & 1 ylldan az & 11 & 10.6 \\
\hline & $1-5$ y1l aras 1 & 23 & 22.1 \\
\hline & 6-10 y1l aras1 & 17 & 16.3 \\
\hline & 11 yıl ve üzeri & 53 & 51.0 \\
\hline & Toplam & 104 & 100 \\
\hline \multirow{5}{*}{ Mesleki Tecrübe Süresi } & 1 yıldan az & 6 & 5.8 \\
\hline & $1-5$ yıl aras1 & 19 & 18.3 \\
\hline & $6-10$ y1l aras1 & 15 & 14.4 \\
\hline & 11 yıl ve üzeri & 64 & 61.5 \\
\hline & Toplam & 104 & 100 \\
\hline
\end{tabular}

Tablo 5'de görüldüğü gibi araştırmaya katılan sağlık çalışanlarının demografik özellikleri incelendiğinde, sağlık çalışanlarının \%52,9'unu erkekler, \%53,8'ini 35 yaş ve üzeri kişiler, \%72,1'ini evliler, \%45,2'ini ön lisans mezunları oluşturmaktadır. Sağglık çalışanlarının unvanları bakımından \%29,8'ini sağlık teknisyeni ve sağlık memuru, \%25'ini röntgen teknisyeni, kıdem süresi bakımından \%51'ini 11 yıl ve üzeri çalışanlar, mesleki tecrübe süresi bakımından ise \%61,5'ini 11 yıl ve üzeri çalışanlar oluşturmaktadır. 


\subsection{Yıldırıcı Davranış ve Alt Boyutlarına Ait Tanımlayıcı İstatistikler}

Yıldırıcı davranış ölçeği maddelerine ait tanımlayıcı istatistiklere Tablo 6'da yer verilmiştir. Buna göre, boyutlar arasında en yüksek değer $(1,7946)$ "mesleki itibara yönelik saldırı ve kendini göstermenin engellenmesi ”, en düşük değer ise $(1,3486)$ "iş ve yaşam kalitesine yönelik saldırı" boyutuna aittir.

Tablo 6. Yıldırıcı davranış maddelerinin tanımlayıcı istatistikleri

\begin{tabular}{|c|c|c|}
\hline MADDELER & Ortalama & $\begin{array}{l}\text { Std. } \\
\text { Sapma }\end{array}$ \\
\hline Mesleki İtibara Yönelik Saldırı ve Kendini Göstermenin Engellenmesi & 1,7946 & $\mathbf{0 , 9 0 8 7 0}$ \\
\hline 10- Performansınızla ilgili sürekli olumsuz değerlendirmeler yapılması & 1.61 & 1.01 \\
\hline 11- Sorumlu olmadığınız konularda suçlanmanız & 1.89 & 1.13 \\
\hline 12- Ortak yapılan işlerin olumsuz sonuçlarından yalnızca sizin sorumlu tutulmanız & 1.75 & 0.94 \\
\hline 13- Yaptığınız iş ve işin sonuçları ile ilgili sürekli kusur/hata bulunması & 1.79 & 1.08 \\
\hline 14- Yaptığınız her işte mesleki yeterliliğinizin sorgulanması & 1.58 & 1.03 \\
\hline 16- Sizin ve yaptığınız işin size hissettirilmeden (dolaylı) kontrol edilmesi & 2.05 & 1.19 \\
\hline 17- Kendinizi göstermenize firsat verilmemesi & 1.94 & 1.17 \\
\hline 27- Kapasitenizin üstünde işlerden sorumlu tutulmanız & 1.75 & 1.10 \\
\hline Kişisel İtibara Yönelik Saldırı & 1,6673 & $\mathbf{0 , 7 5 1 7 8}$ \\
\hline 1- Başkalarının yanında sizinle aşağılayıcı ve onur kırıcı konuşulması & 1.90 & 0.99 \\
\hline 2- Sizinle ilgili asılsız söylemlerde bulunulması & 2.18 & 1.16 \\
\hline 3- Başkalarının yanında size küçük düşürücü davranılması (beden dili kullanılması) & 1.84 & 0.98 \\
\hline 4- Ruh sağlığınızın yerinde olmadığının ima edilmesi & 1.38 & 0.86 \\
\hline 9- Masaya yumruk vurulması gibi davranışlarla karşılaşma & 1.31 & 0.74 \\
\hline 15- Sizinle ilgili haksız gerekçelerle yazışmalar yapılmas1/rapor tutulması & 1.40 & 0.94 \\
\hline İş ve Yaşam Kalitesine Yönelik Saldırı & 1,3486 & 0,74669 \\
\hline 7- Özel yaşantınızla ilgili asılsız söylentiler çıkarılması & 1.49 & 1.07 \\
\hline 28- İşten ayrılmanız ya da yer değiştirmeniz için baskı yapılması & 1.43 & 0.95 \\
\hline 29- İşiniz için gerekli olan bilgi doküman ve materyallerin sizden saklanması & 1.30 & 0.83 \\
\hline 30- Şahsi eşyalarınıza zarar verilmesi & 1.17 & 0.70 \\
\hline Sosyal İlişkilere Yönelik Saldırı & 1,7780 & $\mathbf{0 , 8 7 0 9 6}$ \\
\hline $\begin{array}{l}\text { 19- Sorumluluğunuzda olan işlerin sizden alınarak sizden daha düşük pozisyonda } \\
\text { kişilere verilmesi }\end{array}$ & 1.57 & 0.99 \\
\hline 20- Sizden daha düşük pozisyonda kişiler tarafindan denetlenmeniz & 1.78 & 1.17 \\
\hline 21- Düzenlenen sosyal toplantılardan haberdar edilmeme & 2.05 & 1.18 \\
\hline 22- Görüşme ve konuşma isteğinize yanıt alamama & 1.71 & 0.92 \\
\hline İletişime Yönelik Saldırı & $\mathbf{1 , 3 8 2 2}$ & 0,68262 \\
\hline 23- Bulunduğunuz ortamda görmezden gelinerek, yokmuşsunuz gibi davranılması & 1.61 & 0.95 \\
\hline 24- Gönderdiğiniz elektronik posta ve telefonlara yanıt verilmemesi & 1.39 & 0.81 \\
\hline 25- İş arkadaşlarınızın sizinle konuşmasının engellenmesi ya da yasaklanması & 1.26 & 0.71 \\
\hline 26- Bir ortama girdiğinizde bulunduğunuz ortamın bilerek terk edilmesi & 1.28 & 0.70 \\
\hline
\end{tabular}


Maddeler arasında en yüksek ortalama değer 2,18 ile "kişisel itibara yönelik saldırı" boyutuna ait olan "sizinle ilgili asılsız söylemlerde bulunulması" maddesine ait iken, ikinci sırada 2,05 ortalama değeriyle "mesleki itibara yönelik saldırı ve kendini göstermenin engellenmesi" boyutunda yer alan "sizin ve yaptığınız işin size hissettirilmeden (dolaylı) kontrol edilmesi" ve "sosyal ilişkilere yönelik saldırı boyutuna" ait "düzenlenen sosyal toplantılardan haberdar edilmeme" önermesi oluşturmuştur.

En düşük ortalama değerin 1,17 ile "iş ve yaşam kalitesine yönelik saldırı" boyutuna ait olan "şahsi eşyalarınıza zarar verilmesi" maddesi ve bunu takiben 1,26 ile "iletişime yönelik saldırı" boyutuna ait olan "iş arkadaşlarınızın sizinle konuşmasının engellenmesi ya da yasaklanması" maddesi olduğu görülmektedir.

$\mathrm{Bu}$ verilere göre boyut ortamalarının tamamının 2'nin altında kalması nedeniyle katılımcıların genel olarak yıldırıcı davranışa yoğun bir şekilde maruz kalmadıkları ancak kendileriyle ilgili asılsız söylemlerde bulunulması, yaptıkları işin kendilerine hissettirilmeden (dolayl1) kontrol edilmesi ve düzenlenen sosyal toplantılardan haberdar edilmeme gibi davranışlarla bir kaç kez karşılaştıkları söylenebilir.

\subsection{Mesleki Adanmışlık ve Alt Boyutlarına Ait Tanımlayıcı İstatistikler}

Mesleki adanmışlık ölçeği maddelerine ait tanımlayıcı istatistiklere Tablo 7'de yer verilmiştir. Buna göre, boyutlar arasında en yüksek değerin 4,5264 ortalama ile "mesleğe değer verme", en düşük değerin ise 3,1506 ortalama ile "mesleği sevme" boyutuna aittir. 
Tablo 7. Mesleki adanmışlık maddelerinin tanımlayıcı istatistikleri

\begin{tabular}{|c|c|c|}
\hline MADDELER & Ortalama & $\begin{array}{c}\text { Std. } \\
\text { Sapma }\end{array}$ \\
\hline Mesleği Sevme & 3,1506 & $\mathbf{0 , 9 1 0 5 0}$ \\
\hline 4- Çocuğumun bir sağlık çalışanı olmasını isterim & 2.98 & 1.56 \\
\hline 5- Mesleğimi kendim isteyerek seçtim & 3.64 & 1.55 \\
\hline 10- En güzel mesleğin sağlık mesleği olduğunu düşünüyorum & 2.90 & 1.38 \\
\hline 13- Zaman geçtikçe mesleğimi daha çok severek yapıyorum & 3.44 & 1.36 \\
\hline 21- Yeniden dünyaya gelsem yine de bu mesleği seçerim & 2.93 & 1.50 \\
\hline Haz Alma & 3,6010 & $\mathbf{0 , 9 3 7 0 5}$ \\
\hline 7- Hasta insanlara yardım etmek için bu mesleği (beyaz önlüğü) seçtim & 3.56 & 1.30 \\
\hline 8- Sağlık mesleği zevkli bir meslektir & 3.51 & 1.33 \\
\hline 11- İletişim becerimin daha iyi olduğuna inandığım için bu mesleği seçtim & 3.00 & 1.44 \\
\hline $\begin{array}{l}\text { 12- Hastaların daha iyi sağlık hizmeti almalarında en önemli faktör sağlık } \\
\text { çalışanıdır }\end{array}$ & 4.34 & 0.95 \\
\hline Mesleğe Değer Verme & 4,5264 & 0,66274 \\
\hline $\begin{array}{l}\text { 18- Mesleğimi yaparken hasta ve çalışan işbirliğini (ekip çalışmasını) } \\
\text { önemsiyorum }\end{array}$ & 4.61 & 0.78 \\
\hline $\begin{array}{l}\text { 19- Hastalarımın sağlığına kavuştuğunu gördüğümde mesleğime daha iyi } \\
\text { bağlanıyorum }\end{array}$ & 4.51 & 0.93 \\
\hline 20- Bir insanın sağlığına kavuşmasında sağlık mesleği önemli bir meslektir & 4.66 & 0.72 \\
\hline 22- Sağlik mesleğinin kutsal bir meslek olduğunu düşünüyorum & 4.33 & 1.14 \\
\hline Gayret Gösterme & $\mathbf{3 , 8 0 7 7}$ & 0,92629 \\
\hline 3- Mesleğimle ilgili gelişmeleri takip ediyorum & 3.82 & 1.31 \\
\hline 14- Sağlık mesleği alanında kendimi yeterli buluyorum & 4.16 & 1.08 \\
\hline 15- Mesleki alanında tecrübemi artıracak faaliyetlere katılıyorum & 3.44 & 1.24 \\
\hline Zorlanma & 4,4279 & $\mathbf{0 , 7 6 1 3 8}$ \\
\hline 9- Sağlık mesleği yorucu bir meslektir & 4.31 & 0.94 \\
\hline 17- Sağlık mesleği yıpratıcı bir meslektir & 4.55 & 0.85 \\
\hline
\end{tabular}

Maddeler arasında en yüksek ortalama değerleri 4,66 ile "mesleğe değer verme" boyutuna ait olan "bir insanın sağlığına kavuşmasında sağlık mesleği önemli bir meslektir”, 4,61 ortalama ile "mesleğimi yaparken hasta ve çalışan işbirliğini (ekip çalışmasını) önemsiyorum" ifadeleri almıştır. En düşük ortalama değerin ise 2,90 ile "mesleği sevme" boyutuna ait olan "en güzel mesleğin sağlık mesleği olduğunu düşünüyorum” ifadesine ait olduğu görülmektedir.

$\mathrm{Bu}$ sonuçlara göre boyut ortamalarının tamamının 3'ün üzerinde olması nedeniyle katılımcıların genel olarak kendilerini mesleklerine adayarak değer verdikleri görülmektedir. Böylece ankete katılan sağlık çalışanlarının mesleklerini, insanın sağlığına kavuşmasında önemli gördükleri, hasta ve çalışan işbirliğini önemsedikleri, sağlık mesleğini yıpratıcı bir meslek olarak değerlemelerine rağmen hastaların sağlığına kavuştuklarını gördükçe mesleklerine daha çok bağlanarak kutsal bir iş yaptıklarını düşündükleri söylenebilir. 


\subsection{Yıldırıcı Davranış ile Mesleki Adanmışıı Boyutları Arasındaki İlişskiler}

Araştırmaya katılanların verdikleri cevaba göre yıldırıcı davranış ve mesleki adanmışlık faktörleri arasında anlamlı ilişki olup olmadığını belirlemek için korelasyon analizi yapılmış ve sonuçlar Tablo 8'de gösterilmiştir.

Korelasyon analizinden önce, değişkenler arasında saçılım grafikleri incelenmiş ve hatalı değerlerin olmadığı belirlenmiştir. Daha sonra yıldırıcı davranış ve mesleki adanmışlık faktörleri arasındaki ilişkinin yönü ve şiddetinin belirlenebilmesi için Pearson Korelasyon katsayıları hesaplanmıştır. Korelasyon katsayısı, iki değişken arasındaki ilişkinin ölçüsüdür ve -1 ile +1 arasında değişim gösterir (Kalayc1, 2006: 117).

Tablo 8'deki korelasyon analizi sonuçları incelendiğinde yıldırıcı davranış ile mesleki adanmışlığ 1 etkileyen faktörlerin boyutlarının genel itibarıyla Sig. değerlerinin \%5'den büyük olması bu ilişkilerin istatistiki açından anlamlı olmadığını göstermektedir. Ancak, bir çok yazar anlamlılık düzeyinin belirlenmesini fakat üzerinde durulmaması gerektiğini belirtmektedir (Kalaycı vd., 2006: 112). Bu bilgiye dayanarak, "mesleki itibara yönelik saldırı ve kendini göstermenin engellenmesi” yıldırıcı davranışı ile "mesleği sevme” adanmışlık boyutu arasında negatif yönlü bir ilişkinin görülmesi, yıldırıcı davranışın bu boyutu arttıkça mesleği sevme boyutunun azaldığı (veya yıldırıcı davranışın bu boyutu azaldıkça mesleği sevme boyutunun artacağı) ancak derecesinin $(-0,187)$ çok zayıf olduğu söylenebilir.

Yıldırıcı davranış faktörleri ile mesleki adanmışlık faktörleri arasında yapılan karşılaştırmada ise en güçlü ilişki, "iş ve yaşam kalitesine yönelik saldırı" ile "gayret gösterme" arasında $(r=$,222) iken en zayıf ilişki, "iş ve yaşam kalitesine yönelik saldırı" ile "haz alma" arasında $(\mathrm{r}=, 194)$ olduğu görülmektedir. Yıldırıcı davranış boyutlarından iş ve yaşam kalitesine yönelik saldırılar \%10 artış (azalış) gösterirse gayret gösterme davranışının \% 22,2 haz alma \% 19,4 oranında artış (azalış) göstereceği beklenebilir ki bu çok zayıf ilişki düzeyindedir. Ancak araştırmamızda iş ve yaşam kalitesine yönelik saldırı puan değerlerinin oldukça az adanmışlık boyutlarından gayret gösterme ve haz alma puan değerlerinin oldukça yüksek bulunması söz konusu boyutlar arasında pozitif bir ilişki ortaya çıkmasına neden olmuştur.

Aynı şekilde "mesleği sevme" ile "zorlanma" adanmışlık boyutu arasında (Sig. ,082>,05) olduğundan istatistiksel olarak anlamlı bir ilişki görülmese de korelasyon katsayısı $(-, 171)$ işaretinin negatif olmasından dolayı söz konusu iki boyut arasında meslekte zorlanma 
arttıkça mesleği sevmenin azalmakta (veya meslekte zorlanma azaldıkça mesleği sevme artmakta) olacağı söylenebilir.

Yıldırıcı davranış faktörleri arasındaki en güçlü ilişki, "sosyal ilişkilere yönelik saldırı" ile "iletişime yönelik saldırı" arasında iken $(r=, 707)$, en zayıf ilişki, "kişisel itibara yönelik saldırı" ile "sosyal ilişkilere yönelik saldırı" arasındadır $(\mathrm{r}=, 580)$. Bu boyutlar birbirleriyle etkileşim halinde olduğundan boyutlardan birinde meydana gelen bir artış (azalma) diğer boyutlarda da yüksek düzeyde artma (azalma) gösteceği belirtilebilir.

Tablo 8. Yıldırıcı davranış boyutları ve mesleki adanmışlığı etkileyen faktörler arasındaki ilişki

\begin{tabular}{|c|c|c|c|c|c|c|c|c|c|c|c|}
\hline \multicolumn{12}{|c|}{$\begin{array}{l}\text { Korelasyon Analizi } \\
\end{array}$} \\
\hline & & \multicolumn{5}{|c|}{ Yıldırıcı Davranış Boyutları } & \multicolumn{5}{|c|}{ Mesleki Adanmışlık Faktörleri } \\
\hline & & \begin{tabular}{|c|} 
Mesleki İtibara \\
Yönelik Saldırı \\
ve Kendini \\
Göstermenin \\
Engellenmesi
\end{tabular} & $\begin{array}{c}\text { Kişisel } \\
\text { İtibara } \\
\text { Yönelik } \\
\text { Saldırı }\end{array}$ & $\begin{array}{l}\text { İş ve } \\
\text { Yaşam } \\
\text { Kalitesine } \\
\text { Yönelik } \\
\text { Saldırı }\end{array}$ & $\begin{array}{c}\text { Sosyal } \\
\text { İlişkilere } \\
\text { Yönelik } \\
\text { Saldırı }\end{array}$ & $\begin{array}{l}\text { İletişime } \\
\text { Yönelik } \\
\text { Saldırı }\end{array}$ & $\begin{array}{c}\text { Mesleği } \\
\text { Sevme }\end{array}$ & $\begin{array}{c}\mathrm{Haz} \\
\text { Alma }\end{array}$ & $\begin{array}{l}\text { Mesleğe } \\
\text { Değer } \\
\text { Verme }\end{array}$ & $\begin{array}{c}\text { Gayret } \\
\text { Gösterme }\end{array}$ & Zorlanma \\
\hline \multirow{2}{*}{$\begin{array}{l}\text { Mesleki İtibara } \\
\text { Yönelik Saldırı } \\
\text { ve Kendini } \\
\text { Göstermenin } \\
\text { Engellenmesi }\end{array}$} & \begin{tabular}{|c|} 
Pearson \\
Correlation
\end{tabular} & 1 & & & & & & & & & \\
\hline & $\begin{array}{c}\text { Sig. } \\
\text { (2-tailed) }\end{array}$ & & & & & & & & & & \\
\hline \multirow{2}{*}{$\begin{array}{l}\text { Kişisel İtibara } \\
\text { Yönelik Saldırı }\end{array}$} & \begin{tabular}{|c|} 
Pearson \\
Correlation \\
\end{tabular} &, $684^{* *}$ & 1 & & & & & & & & \\
\hline & \begin{tabular}{|c|} 
Sig. \\
(2-tailed)
\end{tabular} &, 000 & & & & & & & & & \\
\hline \multirow{2}{*}{\begin{tabular}{|} 
İş ve Yaşam \\
Kalitesine \\
Yönelik Saldırı
\end{tabular} \mid} & \begin{tabular}{|c|} 
Pearson \\
Correlation \\
\end{tabular} &, $698^{* *}$ &, $656^{* *}$ & 1 & & & & & & & \\
\hline & $\begin{array}{c}\text { Sig. } \\
\text { (2-tailed) }\end{array}$ &, 000 & ,000 & & & & & & & & \\
\hline \multirow{2}{*}{$\begin{array}{l}\text { Sosyal } \\
\text { Illişkilere } \\
\text { Yönelik Saldırı }\end{array}$} & \begin{tabular}{|c|} 
Pearson \\
Correlation \\
\end{tabular} &, $686^{* *}$ &, $580^{* *}$ &, $645^{* *}$ & 1 & & & & & & \\
\hline & $\begin{array}{c}\text { Sig. } \\
\text { (2-tailed) }\end{array}$ &, 000 & ,000 &, 000 & & & & & & & \\
\hline \multirow{2}{*}{$\begin{array}{l}\text { İletişime } \\
\text { Yönelik Saldırı }\end{array}$} & \begin{tabular}{|c|} 
Pearson \\
Correlation \\
\end{tabular} &, $621^{* *}$ &, $634^{* *}$ &, $624^{* *}$ &, $707^{* *}$ & 1 & & & & & \\
\hline & $\begin{array}{c}\text { Sig. } \\
\text { (2-tailed) } \\
\end{array}$ &, 000 &, 000 & ,000 & ,000 & & & & & & \\
\hline \multirow{2}{*}{ Mesleği Sevme } & \begin{tabular}{c|} 
Pearson \\
Correlation
\end{tabular} &,- 187 &, 010 & ,136 & ,052 & ,084 & 1 & & & & \\
\hline & $\begin{array}{c}\text { Sig. } \\
(2 \text {-tailed) }\end{array}$ &, 057 & ,920 & ,168 & ,601 & ,396 & & & & & \\
\hline \multirow{2}{*}{ Haz Alma } & $\begin{array}{c}\text { Pearson } \\
\text { Correlation } \\
\end{array}$ &, 056 &, 141 &, $194^{*}$ &, 154 &, 113 &, $542^{* *}$ & 1 & & & \\
\hline & $\begin{array}{c}\text { Sig. } \\
\text { (2-tailed) }\end{array}$ &, 572 &, 153 & ,049 & ,118 &, 255 &, 000 & & & & \\
\hline \multirow{2}{*}{$\begin{array}{l}\text { Mesleğe Değer } \\
\text { Verme }\end{array}$} & \begin{tabular}{c|} 
Pearson \\
Correlation \\
\end{tabular} &, 030 & 029 & 105, &,- 054 &, 014 &, $199^{*}$ &, $303^{* *}$ & 1 & & \\
\hline & $\begin{array}{c}\text { Sig. } \\
\text { (2-tailed) }\end{array}$ & ,759 &, 770 & ,289 &, 590 & 891 & 043 & ,002 & & & \\
\hline \multirow{2}{*}{$\begin{array}{l}\text { Gayret } \\
\text { Gösterme }\end{array}$} & $\begin{array}{c}\text { Pearson } \\
\text { Correlation } \\
\end{array}$ &,- 005 &, 042 &, $222^{*}$ &, 007 &,- 021 &, $338^{* *}$ &, $305^{* *}$ &, $279^{* *}$ & 1 & \\
\hline & $\begin{array}{c}\text { Sig. } \\
\text { (2-tailed) }\end{array}$ & ,960 & ,675 & ,024 & ,946 & ,834 & ,000 & ,002 & ,004 & & \\
\hline \multirow{2}{*}{ Zorlanma } & $\begin{array}{c}\text { Pearson } \\
\text { Correlation } \\
\end{array}$ & ,108 &,- 008 & ,066 & ,074 & ,033 &,- 171 &,- 066 & , 124 & ,086 & 1 \\
\hline & $\begin{array}{c}\text { Sig. } \\
\text { (2-tailed) }\end{array}$ &, 275 & ,937 & ,506 & ,456 &, 743 & ,082 &, 504 & ,210 & ,387 & \\
\hline
\end{tabular}


Mesleki adanmışlık faktörleri arasındaki en güçlü ilişki "mesleği sevme" ile "haz alma" arasında $(r=, 542)$ iken en zayıf ilişki, "mesleği sevme" ile "değer verme" $(r=, 199)$ arasındadır. Mesleğini seven bir bireyin haz alarak, zevk duyarak mesleğini icra edeceği düşünülebilir. Araştırmamızda da bu yönde orta düzeyde pozitif bir korelasyon elde edilmiştir. Mesleği sevme ile değer verme arasında yüksek düzey bir ilişki olması beklenebilir. Fakat bu çalışmada çok zayıf pozitif ilişki elde edilmiştir. Bunun sebebinin sağlık çalışanlarının mesleklerini yaparken yaşadıkları sorunlar nedeniyle mesleklerini sevmekten, değer vermekten uzaklaştıkları eğiliminde oldukları düşünülmektedir.

\subsection{Yıldırıcı Davranışın Mesleki Adanmışlık Üzerine Etkisi}

Çalışmanın bu kısmında yıldırıcı davranışın mesleki adanmışlık üzerine etkilerinin ortaya konabilmesi için çoklu regresyon analizi yönteminden yararlanılmıştır. Faktör analizi sonucu (Tablo 2 ve Tablo 4) elde edilen yıldırıcı davranış faktörlerinin, mesleki adanmışlık faktörleri üzerinde ne derece etkisinin olduğunun tespitine yönelik analizler yapılmıştır. $\mathrm{Bu}$ analiz tekniğinde bağımlı değişken mesleki adanmışlık, bağımsız değişken yıldırıcı davranış olarak alınmıştır. Tablo 9, 10, 11, 12, 13'de analizler sonucu ortaya konulan beş regresyon modeli gösterilmiştir. Analiz sonucunda yer alan tüm değişkenler arasındaki ilişki anlamlı $(\mathrm{p}<0,01)$ olduğu için analizlerin tamamı kullanılabilir durumdadır.

\subsubsection{Mesleği sevmeyi etkileyen yıldırıcı davranış boyutları}

Yıldırıcı davranış boyutlarının, mesleki adanmışlığın "mesleği sevme” boyutunu ne ölçüde etkilediğine dair sonuçlara Tablo 9'da yer verilmektedir. Çoklu regresyon analizi sonuçlarına göre, regresyon denklemindeki determinasyon katsayısı değerine göre $(\mathrm{p}=0,000<0,05)$ mesleği sevmede meydana gelen değişimlerin $\% 20,10\left(\mathrm{R}^{2}=0,201\right)$ bağımsız değişkenler olan; "mesleki itibara yönelik saldırı ve kendini göstermenin engellenmesi, kişisel itibara yönelik saldırı, iş ve yaşam kalitesine yönelik saldırı, sosyal ilişkilere yönelik saldırı, iletişime yönelik saldırı” boyutları tarafından açıklanmaktadır. Başka bir ifadeyle, bireyin mesleğini sevme düzeyi \%20,10 oranında bu faktörlere bağlı olarak şekillenmektedir. 
Tablo 9. Yıldırıcı davranış boyutlarının mesleki adanmışlık boyutlarından "mesleği sevme" üzerine etkisi

\begin{tabular}{|c|c|c|c|c|c|c|c|c|}
\hline \multirow[b]{2}{*}{$\begin{array}{l}\text { Bağımlı } \\
\text { Değişken }\end{array}$} & \multicolumn{2}{|c|}{ Model Özeti } & \multicolumn{2}{|c|}{ Anova } & \multicolumn{3}{|c|}{ Katsayılar } & $\begin{array}{l}\text { Durbin } \\
\text { Watson }\end{array}$ \\
\hline & $\mathbf{R}^{2}$ & Düzeltilmiş $\mathbf{R}^{2}$ & $\mathbf{F}$ & $\mathbf{P}$ & $\beta$ & $\mathbf{T}$ & $\mathbf{P}$ & \\
\hline Mesleği Sevme & 0,201 & 0,160 & 4,936 & 0,000 & & & & \\
\hline $\begin{array}{l}\text { Mesleki İtibara } \\
\text { Engellenmesi }\end{array}$ & nelik S & dirı ve Kendini G & sterme & & $-0,677$ & $-4,540$ & 0,000 & 1,573 \\
\hline Kişisel İtibara Y & elik Sal & & & & 0,044 & 0,323 & 0,748 & \\
\hline İş ve Yaşam Kal & sine $Y \ddot{c}$ & elik Saldırılar & & & 0,416 & 2,958 & $0,004 * *$ & \\
\hline Sosyal İlişkilere & önelik S & ldirilar & & & 0,139 & 0,956 & 0,342 & \\
\hline İletişime Yöneli & Saldırıla & & & & 0,119 & 0,843 & 0,402 & \\
\hline
\end{tabular}

$* * p<0,05$ anlaml 1

Tablo 9'daki $\beta$ değerine dayanarak "mesleği sevme” boyutunu etkileyen en önemli bağımsız değişkenin "mesleki itibara yönelik saldırı ve kendini göstermenin engellenmesi” olduğu tespit edilmiştir $(\beta=-0,677, \mathrm{t}=-4,540, \mathrm{p}=0,000)$. Fakat bu değişken, "mesleği sevme" boyutunu negatif yönde etkilemektedir. Söz konusu boyutlarda (dolaylı kontrol edilme, sorumlu olunmayan konularda suçlanma, işin sonuçlarıyla ilgili hata bulunması, yeterliliğinizin sorgulanması vb.) mesleki itibarlarını, iş yaşamlarını irdeleyen ifadeler yer almaktadır. Mesleki itibara yönelik saldırılara maruz kalma düzeyi arttıkça ve kişinin kendini göstermesi engellendikçe bireyin mesleğine olan sevgisinde azalma olacağı söylenebilir.

“İ̧̧ ve yaşam kalitesine yönelik saldırı” değişkeni de mesleği sevme boyutunu pozitif yönde etkilemektedir ( $\beta=0,416, \mathrm{t}=2,958, \mathrm{p}=0,004)$. Her iki boyutla mesleği sevme boyutu arasında anlamlı bir ilişki olduğu ifade edilebilir. Söz konusu boyutlarda mesleki itibarlarını, iş yaşamlarını irdeleyen (sizinle ilgili asılsız söylentiler çıkarılması, işten ayrılma için baskı yapılması vb.) ifadeler yer almaktadır.

Diğer bağımsız değişkenlerin de mesleği sevme boyutu üzerinde bir etkisi olmasına rağmen, bu etkiler istatistiksel açıdan anlamlı değildir. Sonuç olarak, çalışmamıza dahil edilen sağlık çalışanlarının mesleklerine olan sevgilerinin azalmaması için diğer çalışanların daha saygılı davranması gerekmektedir. Yöneticilerin de bu mesleklere özerklik tanımaları, yıldırıcı davranışların önlenmesi yönünde tedbirler almalarının gerekli olduğu söylenebilir.

\subsubsection{Haz almayı etkileyen yıldırıcı davranış boyutları}

Tablo 10'da yıldırıcı davranış boyutlarının, mesleki adanmışlığın "haz alma" boyutunu ne ölçüde etkilediğine dair sonuçlara yer verilmiştir. Buna göre, bağımsız değişkenlerin, haz alma değişkenine ait varyansı \%6,40 oranında açıklanmaktadır. Başka bir ifadeyle, haz alma 
boyutundan duyulan adanmışlık düzeyi $\% 6,40$ oranında bu faktörlere bağlı olarak şekillenmektedir. $\mathrm{Bu}$ orana dayanarak çalışanların yine de mesleklerini yaparken haz duydukları, tatmin oldukları yorumu yapılabilir.

Tablo 10. Yıldırıcı davranış boyutlarının mesleki adanmışlık boyutlarından "haz alma" üzerine etkisi

\begin{tabular}{|c|c|c|c|c|c|c|c|c|}
\hline \multirow[b]{2}{*}{$\begin{array}{l}\text { Bağımlı } \\
\text { Değișken }\end{array}$} & \multicolumn{2}{|c|}{ Model Özeti } & \multicolumn{2}{|c|}{ Anova } & \multicolumn{3}{|c|}{ Katsayılar } & $\begin{array}{l}\text { Durbin } \\
\text { Watson }\end{array}$ \\
\hline & $\mathbf{R}^{2}$ & Düzeltilmiş $\mathbf{R}^{2}$ & \multirow{2}{*}{\multicolumn{2}{|c|}{\begin{tabular}{c|c|}
$\mathbf{F}$ & $\mathbf{P}$ \\
1,332 & 0,257 \\
\end{tabular}}} & $\beta$ & $\mathbf{T}$ & \multirow[t]{2}{*}{$\mathbf{P}$} & \multirow{7}{*}{1,794} \\
\hline Haz Alma & 0,064 & 0,016 & & & & & & \\
\hline \multicolumn{5}{|c|}{$\begin{array}{l}\text { Mesleki İtibara Yönelik Saldırı ve Kendini Göstermenin } \\
\text { Engellenmesi }\end{array}$} & $-0,251$ & $-1,552$ & 0,124 & \\
\hline \multicolumn{5}{|c|}{ Kişisel İtibara Yönelik Saldırı } & 0,103 & 0,692 & 0,491 & \\
\hline \multicolumn{5}{|c|}{ İș ve Yaşam Kalitesine Yönelik Saldırılar } & 0,236 & 1,550 & 0,124 & \\
\hline \multicolumn{5}{|c|}{ Sosyal İlişkilere Yönelik Saldırılar } & 0,150 & 0,953 & 0,343 & \\
\hline \multicolumn{5}{|c|}{ İletissime Yönelik Saldırılar } & $-0,050$ & $-0,330$ & 0,742 & \\
\hline
\end{tabular}

Yıldırıcı davranışın, haz alma boyutu üzerinde istatistiksel açıdan anlamlı bir etkisinin olmadığı görülmesine rağmen $(F=1,332 ; p=0,257>0,05)$, mesleği sevme boyutunda olduğu gibi haz almayı en çok etkileyen yıldırıcı davranış boyutu mesleki itibara yönelik saldırı ve kendini göstermenin engellenmesi olarak tespit edilmiştir. Bu etki iletişime yönelik saldırı boyutuyla beraber negatif yönlüdür. Mesleki itibarı konusunda saldırıya uğrayan, kendisini gösterme fırsatı tanınmayan, iletişimi engellenen birey işini yaparken haz duymak yerine zoraki yapacaktır. Bu durumda özellikle idareciler hizmetin daha iyi yapılması, çalışanların tutulması, işlerini zevkle yapabilmelerini sağlamak için çalışma ortamlarını iyileştirmeleri, olumlu bir örgüt kültürü geliştirmeleri, örgüt iklimini olumlu hale getirmeye yönelik önlemler almaları gerekmektedir. Stresin azaltılması, çalışanların iletişiminin artması için de sosyal ortamlar oluşturulmalıdır.

\subsubsection{Mesleğe değer vermeyi etkileyen yıldırıcı davranış boyutları}

Tablo 11'de yıldırıcı davranış boyutlarının, mesleki adanmışlığın "mesleğe değer verme" boyutunu ne ölçüde etkilediğine dair sonuçlara yer verilmiştir. Buna göre, bağımsız değişkenlerin, mesleğe değer verme boyutuna ait varyansı \%3,70 oranında açıklanmaktadır. Başka bir ifadeyle, değer verme boyutundan duyulan adanmışlık düzeyi \%3,70 oranında bu faktörlere bağlı olarak şekillenmektedir. 
Tablo 11. Yıldırıcı davranış boyutlarının mesleki adanmışlık boyutlarından "mesleğe değer verme" üzerine etkisi

\begin{tabular}{|c|c|c|c|c|c|c|c|c|}
\hline \multirow[b]{2}{*}{$\begin{array}{l}\text { Bağımlı } \\
\text { Değişken }\end{array}$} & \multicolumn{2}{|c|}{ Model Özeti } & \multicolumn{2}{|c|}{ Anova } & \multicolumn{3}{|c|}{ Katsayılar } & $\begin{array}{l}\text { Durbin } \\
\text { Watson }\end{array}$ \\
\hline & $\mathbf{R}^{2}$ & Düzeltilmiş $\mathbf{R}^{2}$ & $\mathbf{F}$ & $\mathbf{P}$ & B & $\mathbf{T}$ & $\mathbf{P}$ & \multirow{7}{*}{2,152} \\
\hline $\begin{array}{l}\text { Mesleğe } \\
\text { Değer Verme }\end{array}$ & 0,037 & $-0,012$ & 0,751 & 0,588 & & & & \\
\hline \multicolumn{5}{|c|}{$\begin{array}{l}\text { Mesleki İtibara Yönelik Saldırı ve Kendini Göstermenin } \\
\text { Engellenmesi }\end{array}$} & 0,021 & 0,130 & 0,896 & \\
\hline \multicolumn{5}{|c|}{ Kişisel İtibara Yönelik Saldırı } & $-0,029$ & $-0,190$ & 0,850 & \\
\hline \multicolumn{5}{|c|}{ İş ve Yaşam Kalitesine Yönelik Saldırılar } & 0,234 & 1,517 & 0,133 & \\
\hline \multicolumn{5}{|c|}{ Sosyal İlişkilere Yönelik Saldırılar } & $-0,225$ & $-1,410$ & 0,162 & \\
\hline \multicolumn{5}{|c|}{ İletişime Yönelik Saldırılar } & 0,031 & 0,203 & 0,840 & \\
\hline
\end{tabular}

Yıldırıcı davranışın her bir boyutunun, mesleğe değer verme boyutu üzerinde istatistiksel açıdan anlamlı bir etkisinin olmadığı görülmüştür $(F=0,751 ; p=0,588>0,05)$. Yine iş ve yaşam kalitesine, sosyal ilişkilere yönelik saldırıların değer vermeyi etkilediği söylenebilir. Örgütte dedikodu döngüsünün azaltılmaya çalışılmasının bu durumu olumlu yönde değiştireceği düşünülebilir. Gerek çalışanlar gerekse yöneticiler iletişim becerilerini geliştirme konusunda istekli olmalı ve hizmet içi eğitim programları ile desteklenmelidir. Yıldırma sürecinin başlamadan önlenmesinin sağlanması için çalışanların davranışlarını düzenleyecek, etik kural, standart ve değerler olmalı, bunlar öncelikle iyi tanımlanmalı ve panel, toplantılarla kabul ettirilmelidir. İşe karşı motivasyonu artırıcı planlamalar yapılmalıdır.

\subsubsection{Gayret göstermeyi etkileyen yıldırıcı davranış boyutları}

Tablo 12'de yıldırıcı davranış boyutlarının, mesleki adanmışlığın "gayret gösterme" boyutunu ne ölçüde etkilediğine dair sonuçlara yer verilmiştir. Buna göre, bağımsız değişkenlerin, gayret gösterme boyutuna ait varyansı \%11,9 oranında açıklanmaktadır. Başka bir ifadeyle, gayret gösterme boyutundan duyulan adanmışlık düzeyi \%11,9 oranında bu faktörlere bağlı olarak şekillenmektedir. Model genel olarak ele alındığında yıldırıcı davranış değişkenleri, adanmışlığın gayret gösterme boyutu üzerinde \%11,9'luk bir etkiye sahiptir $(\mathrm{F}=2,656 ; \mathrm{p}=0,027<0,05)$. 
Tablo 12. Yıldırıcı davranış boyutlarının mesleki adanmışlık boyutlarından "gayret gösterme" üzerine etkisi

\begin{tabular}{|c|c|c|c|c|c|c|c|c|}
\hline \multirow[b]{2}{*}{$\begin{array}{l}\text { Bağımlı } \\
\text { Değişken }\end{array}$} & \multicolumn{2}{|c|}{ Model Özeti } & \multicolumn{2}{|c|}{ Anova } & \multicolumn{3}{|c|}{ Katsayılar } & $\begin{array}{l}\text { Durbin } \\
\text { Watson }\end{array}$ \\
\hline & $\mathbf{R}^{2}$ & Düzeltilmiş $\mathbf{R}^{2}$ & \multirow{2}{*}{$\begin{array}{c}\mathbf{F} \\
2,656\end{array}$} & $\mathbf{P}$ & B & $\mathbf{t}$ & $\mathbf{P}$ & \multirow{7}{*}{1,860} \\
\hline $\begin{array}{l}\text { Gayret } \\
\text { Gösterme }\end{array}$ & 0,119 & 0,074 & & 0,027 & & & & \\
\hline \multicolumn{5}{|c|}{$\begin{array}{l}\text { Mesleki İtibara Yönelik Saldırı ve Kendini Göstermenin } \\
\text { Engellenmesi }\end{array}$} & $-0,221$ & $-1,412$ & 0,161 & \\
\hline \multicolumn{5}{|c|}{ Kişisel İtibara Yönelik Saldırı } & $-0,016$ & $-0,111$ & 0,912 & \\
\hline \multicolumn{5}{|c|}{ İş ve Yaşam Kalitesine Yönelik Saldırılar } & 0,523 & 3,538 & $0,001 * *$ & \\
\hline \multicolumn{5}{|c|}{ Sosyal İlişkilere Yönelik Saldırılar } & $-0,056$ & $-0,367$ & 0,714 & \\
\hline \multicolumn{5}{|c|}{ İletişime Yönelik Saldırılar } & $-0,160$ & $-1,083$ & 0,282 & \\
\hline
\end{tabular}

Tablo 12'deki $\beta$ değerine dayanarak “iş ve yaşam kalitesine yönelik saldırı" boyutunun, "gayret gösterme" boyutunu etkileyen en önemli bağımsız değişken olduğu ve bu iki değişken arasında anlamlı ve pozitif bir ilişki bulunduğu $(\beta=0,523, \mathrm{t}=3,538, \mathrm{p}=0,001)$ söylenebilir. $\mathrm{Bu}$ sonuca dayanarak, sağlık çalışanlarının mesleklerini yapma konusunda maruz kaldıkları yıldırıcı davranışlara (özel hayatla ilgili asılsız söylentiler, işten ayrılması için baskılar vb.) rağmen bilinçli, istekli ve gayretli oldukları şeklinde değerlendirilebilir. Sağlık mesleğinde hizmetin hasta ve yakınlarına sunulması bu alanı önemli ve kutsal kılmaktadır. Elde edilen bu sonuç da bu fikri doğrular niteliktedir.

Gayret gösterme boyutunu etkileyen diğer bağımsız değişkenler arasında ise istatistiksel olarak anlamlı bir ilişki bulunmamakla beraber mesleki itibara yönelik saldırıların gayret göstermeyi negatif etkilediği görülmektedir.

\subsubsection{Zorlanmayı etkileyen yıldırıcı davranış boyutu}

Tablo 13'de yıldırıcı davranış boyutlarının, mesleki adanmışlığın “zorlanma” boyutunu ne ölçüde etkilediğine dair sonuçlara yer verilmiştir. Buna göre, bağımsız değişkenlerin, zorlanma boyutuna ait varyansı \%2,6 oranında açıklanmaktadır. Başka bir ifadeyle, zorlanma boyutundan duyulan adanmışlık düzeyi \%2,6 oranında bu faktörlere bağlı olarak şekillenmektedir. 
Tablo 13. Yıldırıcı davranış boyutlarının mesleki adanmışlık boyutlarından "zorlanma" üzerine etkisi

\begin{tabular}{|c|c|c|c|c|c|c|c|c|}
\hline \multirow[b]{2}{*}{$\begin{array}{l}\text { Bağımlı } \\
\text { Değişken }\end{array}$} & \multicolumn{2}{|c|}{ Model Özeti } & \multicolumn{2}{|c|}{ Anova } & \multicolumn{3}{|c|}{ Katsayılar } & \multirow[t]{2}{*}{$\begin{array}{l}\text { Durbin } \\
\text { Watson }\end{array}$} \\
\hline & $\mathbf{R}^{2}$ & Düzeltilmiş $\mathbf{R}^{2}$ & $\mathbf{F}$ & $\mathbf{P}$ & $\boldsymbol{\beta}$ & $\mathbf{t}$ & $\mathbf{P}$ & \\
\hline Zorlanma & 0,026 & $-0,024$ & 0,514 & 0,765 & & & & \multirow{6}{*}{1,665} \\
\hline \multicolumn{5}{|c|}{$\begin{array}{l}\text { Mesleki İtibara Yönelik Saldırı ve Kendini Göstermenin } \\
\text { Engellenmesi }\end{array}$} & 0,186 & 1,127 & 0,262 & \\
\hline \multicolumn{5}{|c|}{ Kişisel İtibara Yönelik Saldırı } & $-0,162$ & $-1,068$ & 0,288 & \\
\hline \multicolumn{5}{|c|}{ İş ve Yaşam Kalitesine Yönelik Saldırılar } & 0,037 & 0,237 & 0,813 & \\
\hline \multicolumn{5}{|c|}{ Sosyal İlişkilere Yönelik Saldırılar } & 0,037 & 0,234 & 0,816 & \\
\hline \multicolumn{5}{|c|}{ İletişime Yönelik Saldırılar } & $-0,030$ & $-0,191$ & 0,849 & \\
\hline
\end{tabular}

$* * \mathrm{p}<0,05$ anlaml 1

Yıldırıcı davranışın her bir boyutunun, "zorlanma" boyutu üzerinde istatistiksel açıdan anlamlı bir etkisinin olmadığ 1 görülmüştür $(F=0,514 ; p=0,765>0,05)$. Y1ldırıcı davranışa maruz kalma düzeyi ile mesleki adanmışlık arasında negatif yönlü bir ilişki olması beklenirken bu çalışmadaki verilere göre katılımcılar tarafından yıldırıcı davranışa maruz kalma değerlemesi oldukça düşük, adanmışlık yüksek seviyede belirlenmiştir. Bu sonuca göre mesleki adanmışlık yıldırıcı davranışlardan bazı durumlarda etkilenmiştir yorumu yapılabilir.

\subsection{Hipotez Analizi Sonuçları}

Gerekçe ve yöntem kısmında oluşturulan hipotezler analize tabi tutulmuş ve böylece elde edilen sonuçlar Tablo 14'de sunulmuştur.

Tablo 14. Hipotez analizi sonuçları

\begin{tabular}{|c|c|c|c|c|c|}
\hline $\begin{array}{l}\text { Yıldırıcı davranış boyutları ile } \\
\text { mesleki adanmışlık boyutları } \\
\text { arasında anlamlı bir ilişki vardır }\end{array}$ & $\begin{array}{c}\mathrm{B}_{1} \\
\text { Mesleği } \\
\text { Sevme }\end{array}$ & $\begin{array}{c}\mathrm{B}_{2} \\
\text { Haz Alma }\end{array}$ & $\begin{array}{c}\mathrm{B}_{3} \\
\text { Mesleğe Değer Verme }\end{array}$ & $\begin{array}{c}\mathrm{B}_{4} \\
\text { Gayret Gösterme }\end{array}$ & $\begin{array}{c}\mathrm{B}_{5}: \\
\text { Zorlanma }\end{array}$ \\
\hline $\begin{array}{l}\mathrm{A}_{1}: \text { Mesleki İtibara Yönelik } \\
\text { Saldırı ve Kendini Göstermenin } \\
\text { Engellenmesi }\end{array}$ & $\sqrt{ }$ & $\mathrm{X}$ & $\mathrm{X}$ & $\mathrm{X}$ & $\mathrm{X}$ \\
\hline $\mathrm{A}_{2}$ : Kişisel İtibara Yönelik Saldırı & $\mathrm{X}$ & $\mathrm{X}$ & $X$ & $\mathrm{X}$ & $\mathrm{X}$ \\
\hline $\begin{array}{l}\mathrm{A}_{3}: \text { Sosyal İlişkilere Yönelik } \\
\text { Saldırı }\end{array}$ & $\mathrm{X}$ & $X$ & $X$ & $\mathrm{X}$ & $\mathrm{X}$ \\
\hline $\mathrm{A}_{4}$ : İletişime Yönelik Saldırı & $\mathrm{X}$ & $\mathrm{X}$ & $\mathrm{X}$ & $\mathrm{X}$ & $\mathrm{X}$ \\
\hline $\begin{array}{l}\mathrm{A}_{5}: \text { İş ve Yaşam Kalitesine } \\
\text { Yönelik Saldırı }\end{array}$ & $\sqrt{ }$ & $\sqrt{ }$ & $\mathrm{X}$ & $\sqrt{ }$ & $\mathrm{X}$ \\
\hline
\end{tabular}

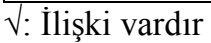

$\mathrm{X}$ : İlişsi yoktur 


\section{TARTIŞMA}

Yapılan analizler sonucunda elde edilen bulgular tartışılarak yıldırıcı davranışa maruz kalma ve mesleki adanmışlık düzeyleri ile ilgili yapılan çalışmaların bulguları aşağıda karşılaştırılmıştır.

Ayrancı vd. (2002) ve Ayrancı vd. (2006) yapmış olduğu çalışmalarında yıldırıcı davranışa maruz kalınmayı mesleki unvanlara göre incelemişlerdir. Buna göre, yıldırıcı davranışla karşılaşma sıklığının sırasıyla hemşireler, pratisyen hekimler, uzman hekimler ve diğer sağlık çalışanlarınca olduğunu tespit etmişlerdir. Bu çalışma ise sadece diğer sağlık çalışanları üzerine odaklanmaktadır.

Çalışmamızda sağlık çalışanlarının yıldırıcı davranışa maruz kalma düzeyleri incelendiğinde, mesleki itibara yönelik saldırı ve kendini göstermenin engellenmesi davranışı 1,7946 puan ile diğer yıldırıcı davranış boyutlarından daha yüksek olduğu saptanmıştır. Bunu sırasıyla sosyal ilişkilere yönelik saldırılar $(1,7780)$ ile kişisel itibara yönelik saldırı $(1,6673)$ boyutları takip etmiştir. Yıldırıcı davranış boyutlarının ortalaması 1,5941 olarak hesaplanmıştır.

Ayrancı vd. (2006)'ın ve Üye (2009)'un sağlık kurumlarında yapmış olduğu bir çalışmada, sözel yıldırıcı davranışın fiziksel yıldırıcı davranıştan daha sık olduğunu ortaya koymuştur. Çalışmamızda da benzer şekilde sözel yıldırıcı davranışın (başkalarının yanında aşağılayıcı ve onur kırıcı konuşulması, hakkında asılsız söylemlerde bulunulması vb.), Dündar (2010) de "sözünüz sürekli kesilir" ifadesinin fiziksel yıldırıcı davranıştan (masaya yumruk vurulması vb.) daha yüksek olduğu belirlenmiştir.

Elliott (1997) ve Kingma (2001), sağlık çalışanlarının yıldırıcı davranışa uğrama riskinin diğer hizmet sektörü çalışanlarına oranla 16 kat daha fazla olduğunu tespit etmişlerdir.

Çöl (2008: 130) işyerinde maruz kalınan ya da tanıklık edilen yıldırıcı davranışların sorumlusu olarak algılanan saldırganlar arasında cinsiyet bakımından bir fark bulamamıştır. Saldırganlar genellikle yükseköğrenim mezunu, doktor, idari personel, hemşireler ile yöneticilerdir. Saldırganlık eğiliminin en az olduğu düşünülen gruplar ise, taşeron işçilerle geçici personel olmuştur. Dilman, (2007) yaptığı çalışmasında hemşirelerin en çok doktorlar tarafından yıldırıcı davranışa maruz bırakıldıklarını tespit etmiştir.

Yapılan çalışmalar sağlık çalışanlarının \%18 ile \%37 oranında kasten yıldırıcı davranışa maruz kaldığını, \%74 ile \%91'inin bir veya birden fazla yıldırıcı davranışla karşılaştığını ve 
çalışanların çoğunun işyerinde çalışma arkadaşlarının bu tür davranışlara maruz kaldıklarına tanık olduklarını göstermektedir (Davenport vd., 2003).

Dünya Sağlık Örgütü, Uluslararası Çalışma Örgütü ve Uluslararası Hemşireler Konseyi 2002 yılı ortak raporunda, farklı ülkelerde sağlık çalışanlarına yönelik şiddet oranlarına bakıldığında, genel olarak çalışanların \%3-\%17'sinin fiziksel, \%27-\%67'sinin sözel, \%10\%23'ünün psikolojik, \%0,7-\%8'inin cinsel içerikli, \%0,8-\%2,7'sinin ise etnik şiddete uğradıkları bildirilmiştir. Sağlık kurumlarında yaşanan her tür şiddet davranışlarını, kadınların erkeklerden daha fazla yaşadığı tahmin edilmektedir (Fronteira vd., 2003).

Diğer taraftan erkeklerin çoğunlukta olduğu işyerlerinde fiziksel yıldırıcı davranışın, kadınların yoğun olduğu işyerlerinde ise psikolojik yıldırıcı davranışın daha sık görüldüğü, kadınların özellikle kendi cinslerine karşı pasif-saldırgan davranışlar sergilediği belirtilmektedir (Björkqvist, 2001). Yıldırıcı davranışların sağlık sektöründe daha fazla oranda görülmesinin sebebi kadın çalışanların çokluğu ile ilişkilendirilmekte ve kadınların diğer kadınlara karşı pasif-saldırgan davranışlar sergilemeyi tercih etmeleri ile açıklanmaktadır. Türkiye'de yapılan araştırmalarda hem sözel hem de fiziksel yıldırıcı davranış türlerinin en fazla hasta yakınları tarafından gerçekleştiği, uluslararası yayınların çoğunda ise hastaların, hasta yakınlarından daha fazla saldırıda bulunduğu görülmektedir (Özcan, 2011).

Ülkemizde yıldırıcı davranış kavramına yönelik olarak sağlık çalışanlarına uygulanan çalışmalardan bazılarının sonuçları şu şekilde olmuştur; gündüz vardiyasında çalışan hemşirelerin $(\% 18,2)$ fiziksel saldırılara maruz kaldığ 1 (Öztunç, 2001); kadınların, 39 yaş ve altındakilerin, ayrıca devlet hastaneleri ve birinci basamak sağlık hizmetlerinde çalışanların yıldırıcı davranışla karşılaştıkları (Ayrancı, 2002); yıldırıcı davranışı uygulayanların daha çok üst yöneticiler oldukları; yıldırıcı davranışa karşı verdikleri tepkinin en fazla arkadaşlarıyla bu durumu paylaşmak olduğu (Çöl, 2008); cinsel taciz ve özel hayatla ilgili söylentilerin özel sektörde daha yüksek oranlarda olduğu (Aksoy, 2008); özel ve kamu hastanelerinde dikey ve horizontal yıldırıcı davranışların görüldüğ̈̈ belirlenmiştir.

Sağlık çalışanlarının bağlılıkları üzerinde yapılan çalışmalarda, yaşın, yükselişin, çalışma yılının, deneyimin, yol göstericiliğin, meslekî istihdam boyutunun geniş olmasının bağlılı̆̆ı arttıracağı ifade edilmiştir (Waugaman ve Lohrer, 2000: 53). Bunun yanında 12 yaşın altındaki çocuğu olan kadınların, yüksek kazançlı işe sahip eşi olan kadınların, mesleğe bağlılık düzeyinin düşük olabileceği belirtilmektedir (Kırel, 1999: 118). Bunun yanında hemşirelerle 
ilgili araştırmalarında Mayer ve Allen (1997), hemşirelerin kendi seçimi olan klinik alanda ve kendi seçimi olan coğrafi alanda çalışmasını meslekî ve örgütsel bağlılığı etkileyen etmenler olarak değerlendirmişlerdir.

Şimşek ve Aslan (2012) hemşireler üzerinde yapmış oldukları çalışmanın sonucuna göre, meslekî bağlılık, örgütsel bağl1lıkla ilişkili bulunmuştur. En büyük ilişkiyi örgüte devamlılık bağl1lığıyla, mesleğe devamlılık bağl1lığı göstermektedir. Hemşirelik mesleğinin özerk olması, meslekî bağlılıkla ilişkili bulunmuş ve Fallacaro ve $\mathrm{Wu}$, özerkliğin, iş doyumunun göstergesi olduğunu da tespit etmişlerdir (Waugaman ve Lohrer, 2000: 49; Cohen, 2006: 237; Jenkins, 2005: 30). Ayrıca, özerkliğin, yaşam doyumunu ve duygusal bağlılığ1 etkilediği sonucuna da ulaşılmıştır (Jenkins, 2005: 30).

Çelik (2008) ilköğretim okullarında görev yapan eğitim yöneticilerinin benimsedikleri yönetim modelleri ile öğretmenlerin mesleki adanmışlıkları arasındaki ilişkiyi incelediği çalışmasında, eğitim yöneticilerinin yönetim modelleri ile öğretmenlerin mesleğe adanmışlıkları arasında ilişki olduğu sonucuna ulaşmıştır. Demirhan (2010) eğitim yöneticilerinin yönetsel tarzları ile öğretmenlerin adanmışlık ve tükenmişlik düzeyleri arasındaki ilişkiyi incelemiştir. Turhan vd. (2012)'nin yapmış oldukları araştırmada elde edilen bulgulara göre; sınıf öğretmenlerinin mesleğe adanmışlık düzeylerinin 5 faktörlü bir yapı gösterdiği görülmektedir. Sağlık çalışanları üzerine yapılan bu çalışmada da mesleki adanmışlık 5 faktörlü yap1 (mesleği sevme, değer verme, gayret gösterme, haz alma ve zorlanma) göstermiştir.

\section{SONUÇ VE ÖNERILER}

Sağlık alanında farklı branş gruplarının bir arada çalışması zaman içinde giderek artan anlaşmazlıklara, çatışmalara ve birer yıldırıcı davranışa dönüşebilmekte ve kişilerin hayatlarını ve kurumları olumsuz yönde etkileyebilmektedir. Yıldırıcı davranışlar çalışanların mesleki adanmışlıklarını etkileyerek, hastalara sunulan hizmet kalitesinin azalmasına, kurumun maddi ve manevi açıdan zarar görmesine yol açmaktadır.

Çalışma bulgularından elde edilen sonuçlar ve bunlara yönelik öneriler aşağıda sunulmuştur.

En fazla karşılaşılan yıldırıcı davranış boyutunun "mesleki itibara yönelik saldırı ve kendini göstermenin engellenmesi”, olduğu görülmüştür ve çalışanlarda farklı şekillerde ortaya 
çıkmıştır. Bu boyutu ölçen sorularda, en fazla katılım "sizin ve yaptı̆̆ınız işin size hissettirilmeden (dolaylı) kontrol edilmesi” ifadesine olmuştur. İkinci sırada en çok görülen yıldırıcı davranış boyutu "sosyal ilişkilere yönelik saldırı" olarak belirlenmiştir ve bu boyutta en yüksek ortalama “düzenlenen sosyal toplantılardan haberdar edilmeme” sorusunda olmuştur. Üçüncü sırada karşılaşılan yıldırıcı davranış "kişisel itibara yönelik saldırı” boyutudur. Bu boyutta "sizinle ilgili asılsız söylemlerde bulunulması" ifadesine en yüksek katılım gösterilmiştir. Dördüncü sıradaki yıldırıcı davranış boyutu "iletişime yönelik saldırı” olarak belirlenmiştir. Bu boyutta çalışanlar "görmezden gelinerek, yokmuşsunuz gibi davranılması" ifadesinde hemfikir oldukları tespit edilmiştir. Son yıldırıcı davranış boyutu "iş ve yaşam kalitesine yönelik saldırı" olarak belirlenmiştir. Bu boyutta en yüksek ortalama "özel yaşantınızla ilgili asılsız söylentiler çıkarılması", ifadesi olmuştur. Bu sorunların çözümüne yönelik ve dahi bu tür sorunların ortaya çıkmasını önlemek adına alınabilecek tedbirler aşağıda verilmiştir.

Sağlık hizmeti sunumu bir ekip işidir. Hekimlerin, hemşirelerin, biyolog, teknisyen, fizyoterapist vb. sağlık çalışanının birbirlerinin işlerini dolaylı yada direk kontrol etmek yerine kendi mesleklerinde daha iyi neler yapılabilir, nasıl daha iyi hizmet edilebilir diye dayanışma içinde gayret göstermesi gerekmektedir. Hastane yönetiminin iş karneleri düzenleyerek objektif bir şekilde değerleme yapması, çalışanların kontrolu ve performansları konusunda daha etkili olabilir. Çalışanların davranışları gözlemlenmeli ve etik ilkelere uygun davrananlar ödüllendirilmeli, iş karnelerinin içine etik davranma konusunda ilaveler yapılmalıdır.

Hastanedeki toplantılardan ve alınan kararlardan tüm personel haberdar edilmeli, katılımları sağlanmalıdır. Bu toplantılar periyodik olarak tüm personeli kapsayacak şekilde düzenlenmelidir. Yönetim, kurum içi motivasyon ve iletişimi, sosyal olguları, çalışanlarının ihtiyaçlarını belirlemeli ve motivasyonu, iletişimi artırıcı ortamlar hazırlamalıdır.

Kurumlarda insan kaynakları yönetim birimi kurulmalıdır. $\mathrm{Bu}$ birim yıldırıcı davranışlara neden olabilecek riskli durumları belirlemeli, yönetim kademesi ile çalışanlar arasındaki bağlantıyı sağlayarak çalışanların sorunlarının çözümüne dair önerileri yönetime sunmalıdır. Ayrıca bu birim tüm çalışanlara (hekim, hemşire, diğer branşlar, şirket personelleri dahil) etik davranışlar, hastaya yaklaşım, yıldırıcı davranışlarla baş etme, önleme gibi konularda eğitim seminerleri düzenleyerek katılımlarını sağlamalıdır. Hakkında asılsız söylenti çıkan kişiye de kendini savunma hakkı tanınmalıdır. Kurumda oluşturulacak psikolojik ve rehberlik danışma birimi tarafından sorun yönetim birimine iletilmeli mağdura psikolojik destek 
sağlanmalıdır. Sağlık sektöründe yıldırıcı davranışların düzenli olarak bildirilip raporlanmadığı için ne sıklıkta ve ne türde gerçekleştiği doğru bir şekilde bilinemediği yapılan araştırmalarda tespit edilmiştir (Annagür, 2010: 163). Çalışanlar çok uzun süreyle aynı birimde ve aynı kişilerle çalıştırılmamalıdır. Departmanlar arasında personel değişikliği yapılmalıdır.

Yıldırıcı davranışa maruz kalma ve mesleki adanmışlık boyutları arasındaki ilişkiyi görebilmek için yapılan korelasyon analizi sonucunda en güçlü ilişki, "iş ve yaşam kalitesine yönelik saldırı" ile "gayret gösterme” arasında ve pozitif yönlü bulunmuştur. İş ve yaşam kalitesine yönelik saldırılar kurum içinde çalışanın özel hayatını, şahsını, işteki performansını, çalışma ortamındaki ilişkilerini belirleyen ve etkileyen boyutlardandır. Bu yüzden çalışanların saldırıları şahsi değerlendirmelerinden dolayı mesleki olarak gayretleri devam etmektedir. Bunun yanında "mesleki itibara yönelik saldırı ve kendini göstermenin engellenmesi” yıldırıcı davranışı ile "mesleği sevme" adanmışlık boyutu arasında negatif yönlü bir ilişki ortaya çıkmıştır. Bu durumda saldırıların mesleki konularda olmasından dolayı çalışanların mesleklerine olan sevgileri azalma göstermiştir. Boyutların kendi içindeki korelasyon analizine göre; yıldırıcı davranış boyutları arasındaki en güçlü ilişki, "sosyal ilişkilere yönelik saldırı" ile “iletişime yönelik saldırı” arasında gerçekleşmiş̧tir. İnsan sosyal ortamda iletişim kurar. Bu sebeple kişinin iletişiminin engellenmesi sosyal ilişkilerine de zarar verecektir. Mesleki adanmışlık boyutları arasındaki en güçlü ilişki "mesleği sevme" ile "haz alma" arasındadır. Mesleğini seven bir kişinin, uygun şartlarda da çalışıyorsa, sonuçlardan duyacağı haz yüksek olacaktır. Kişiler mesleklerini seçerken daha yolun başında iken sevdikleri meslekleri seçmelidirler ve yöneticiler de çalışanlara iş ortamlarını psikolojik ve fizyolojik yönden çalışma şartlarına uygun hale getirmelidirler.

Yıldırıcı davranış boyutlarının mesleki adanmışlık düzeyine etkilerinin incelenmesinde çoklu regresyon analizi testinden yararlanılmıştır. Bağımlı değişkenlerden olan "mesleği sevme" boyutu \%20,10 oranında, "gayret gösterme" boyutu \%11,19 oranında bağımsız değişkenlere bağlı olarak şekillenmektedir. "Mesleği sevme" boyutunu etkileyen en önemli bağımsız değişkenin "mesleki itibara yönelik saldırı ve kendini göstermenin engellenmesi" olduğu ve negatif yönde etkilediği tespit edilmiştir. "İş ve yaşam kalitesine yönelik saldırı" bağımsız değişkeni de "mesleği sevme” boyutunu pozitif yönde etkilemektedir. "İş ve yaşam kalitesine yönelik saldırı" boyutunun, gayret göstermeyi etkileyen en önemli bağımsız değişken olduğu ve bu iki değişken arasında anlamlı bir ilişki bulunduğu belirlenmiştir. Mesleki tecrübeyi artıracak faaliyetlere katılmayı, meslekle ilgili gelişmeleri takip etmeyi, mesleki yeterliliği belirleyen gayret gösterme boyutu yıldırıcı davranış boyutlarından iş ve yaşam 
kalitesine yönelik saldırı boyutundan pozitif yönde etkilenmektedir. Çalışanlar işlerine yönelik saldırılar arttıkça mesleklerini daha iyi yapabilmek, ispat edebilmek, yılmamak için daha fazla gayret içine girmektedirler. Yöneticiler çalışanların bu gayretlerini değerlendirmeli onlara mesleki eğitim olanaklarını sağlamalıdır. Motivasyonu yüksek, çalışkan, istekli, mesleğini seven personel ödüllendilmelidir. İnsan kaynakları yönetim birimi işe alımlarda mesleğini seven gayretli insanları seçme konusunda özen göstermelidir. Yönetimin çalışanlara iş karneleri düzenleyerek objektif değerleme yapmaları, çalışanlar arasında departman değişikliği yapılması mesleki yönden çalışanların mesleki itibarlarına yönelik saldırıları azaltacak, kendilerini göstermelerine fırsat sağlayacaktır. Saldırıya maruz kalanların kurumdaki insan kaynakları ya da mobbing birimine durumu bildirmeleri konusunda cesaretlendirilmeleri önemlidir. Çalışanlar yasal hakları ve mobbing konusunda bilinçlendirilmelidir.

\section{REFERENCES / KAYNAKLAR}

Aksoy, F. (2008). Psikolojik şiddet'in (mobbing) sağllk çalışanlarına etkisi (Doktora tezi). Marmara Üniversitesi, İstanbul.

Altıntaş, N. (2006). Sağllk kurumlarında çalışan hemşirelere yönelik şiddetin belirlenmesi (Yüksek lisans tezi). İstanbul Üniversitesi, İstanbul.

Annagür, B. (2010). Sağlık çalışanlarına yönelik şiddet: Risk faktörleri, etkileri, değerlendirilmesi ve önlenmesi. Psikiyatride Güncel Yaklaşımlar, 2(2), 161-173.

Arısoy, A. (2011). Mobbingi ortaya çıkaran faktörler: Isparta Antalya-Burdur'da sağllk sektöründe hemşireler üzerine çalışma (Yüksek isans tezi). Süleyman Demirel Üniversitesi, Isparta.

Ayranc1, Ü. (2005). Violence toward health care workers in emergency departments in west Turkey. The Journal of Emergency Medicine, 28(3), 361-365.

Ayrancı, Ü., Yenilmez, Ç. \& Günay, Y. (2002). Çeşitli sağlık kurumlarında ve sağlık meslek gruplarında şiddete uğrama sıklığı. Anadolu Psikiyatri Dergisi, (3), 147-154.

Ayrancı, Ü., Yenilmez, Ç., Balcı, Y. \& Kaptanoğlu, C. (2006). Identification of violence in Turkish health care settings. The Journal of Interpers Violence, 21(2), 276-296.

Belikırık, D. (2009). Asistan doktorlarda yıldırma algısı ve bir alan araştırması (Yüksek lisans tezi). Sakarya Üniversitesi, Sakarya.

Björkqvist, K. (2001). Social defeat as a stressor in humans. Physiology\& Behavior, 73, 435-442.

Cohen, J. D. (2006). The aging nursing workforce: How to retain experienced nurses. Journal of Healthcare Management, Jul/Aug, 51(4), 233-245.

Çelik, S. (2008). İlkögrretim okullarındaki eğitim yöneticilerinin yönetim modelleri ile öğretmenlerin mesleki adanmışlığının ilişkisi (Yüksek lisans tezi). Yeditepe Üniversitesi, İstanbul.

Çobanoğlu, Ş. (2005). Mobbing, iş yerinde duygusal saldırı ve mücadele yöntemleri. İstanbul: Timaş Yayınları. 
Çöl, S. Ö. (2008). İşyerinde psikolojik şiddet: Hastane çalışanları üzerine bir araştırma. Çalışma ve Toplum Dergisi, 4, 107-134.

Dahlberg, L. L., Krug, E. G., Mercy, J. A. \& Zwi, A. B. (2002). The world report on violence and health. The Lancet, 360(9339), 3-19. DOI: https://doi.org/10.1016/S0140-6736(02)11133-0

Davenport, N., Schwartz, R. D., Elliott, G. P. \& Vidali, S. (2003). Mobbing: İsyerinde duygusal taciz (O. C. Önertoy, Çev.). İstanbul: Sistem Yayıncılık.

Demirhan, G. (2010). Ĕgitim yöneticilerinin yönetsel tarzları ile ögretmenlerin adanmışlık ve tükenmişlik düzeyleri arasındaki ilişki (Yüksek lisans tezi). Uşak Üniversitesi, Uşak.

Dikmetaş, E., Top, M. \& Ergin, G. (2011). Asistan hekimlerin tükenmişlik ve mobbing düzeylerinin incelenmesi. Türk Psikiyatri Dergisi, 22(3), 137-149.

Dilman, T. (2007). Özel hastanelerde çalışan hemşirelerin duygusal tacize maruz kalma durumlarının incelenmesi (Yüksek lisans tezi). Marmara Üniversitesi, İstanbul.

Dündar, T. (2010). Sağlık çalışanlarının yıldırmaya maruz kalmalarında hastane etik iklimi ile sosyodemografik özelliklerinin rolü: Bolu ili hastanelerinde bir araştırma (Yüksek lisans tezi). Hacettepe Üniversitesi, Ankara.

Elliott, P. P. (1997). Violence in health care, what nurse managers need to know. Nurs Manage, 28(12), 38-41.

Fronteira, I., Craveiro, I., Antunes, A. R., Conceiçao, C., Flores, I. \& Santos, O. (2003). Patterns of perceptions of workplace violence in the portuguese health care sector. Human Resources for Health, 1-11.

Jenkins, D. (2005). Examining the relationships between the satisfaction of basic psychological needs, employee well-being, \& commitment (Unpublished Master Dissertation). Carleton University, Ottowa.

Kalayc1, Ş. (2006). SPSS uygulamalı çok değişkenli istatistik teknikleri (2. Baskl). Ankara: Asil Yayın.

Kırel, Ç. (1999). Esnek çalışma saatleri uygulamalarında cinsiyet, iş tatmini ve iş bağlılığı ilişkisi. İstanbul Üniversitesi İsletme Fakültesi Dergisi, 2(28), 115-136.

Kingma, M. (2001). Workplace violence in the health sector: A problem of epidemic proportion. International Nursing Review, 48, 129-130.

Özcan, N. K. (2011). Türkiye'de sağlık çalışanlarına yönelik şiddet: Sistematik derleme. Türkiye Klinikleri Tıp Bilimleri Dergisi, 31(6), 1442-1456.

Özdamar, K. (2004). Paket programlar ile istatistiksel veri analizi-I. Eskişehir: Kaan Kitabevi.

Öztunç, G. (2001). Adana ilindeki çeşitli hastanelerde çalışan hemşirelerin çalışma saatlerinde karşılaştıkları sözel ve fiziksel taciz olaylarının incelenmesi. Cumhuriyet Üniversitesi Hemşirelik Yüksekokulu Dergisi, 5(1), 1-9.

Saines, J. C. (1999). Violence and aggression in a\&e: Recommendations for action. Accid Emerg Nurs, (7), 8-12.

Şencan, H. (2005). Sosyal ve davranışsal ölçümlerde güvenilirlik ve geçerlilik. Ankara: Seçkin Yayıncılık.

Şimşek, Ş. \& Aslan, Ş. (2012). Meslekî ve örgütsel bağlılığın, örgütsel davranışa ilişkin sonuçlarla ilişkileri. Selçuk Üniversitesi IIBF Sosyal ve Ekonomik Araştırmalar Dergisi, 23(12), 415-454.

Turhan, M., Demirli, C. \& Nazik, G. (2012). Sınıf öğretmenlerinin mesleğe adanmışlık düzeyine etki eden faktörler: Elazığ örneği. İstanbul Ticaret Üniversitesi Sosyal Bilimler Dergisi, 21(11), 179-192.

Üye, C. (2009). Hemşirelerin yöneticileri tarafindan mobbing davranışları ile karşılaşma durumlarının belirlenmesi (Yüksek lisans tezi). Haliç Üniversitesi, İstanbul. 
Waugaman, W. R. \& Lohrer, D. J. (2000). From nurse to nurse anesthetist: The influence of age and gender on professional socialization and career commitment of advanced practice nurses. Journal of Professional Nursing, $16(1), 47-56$.

Wu, L. \& Norman, I. J. (2006). An investigation of job satisfaction, organizational commitment and role conflict and ambiguity in a sample of Chinese undergraduate nursing students. Nurse Education Today, (26), 304-314.

Y1ldırım, A. \& Y1ldırım, D. (2007). Mobbing in nursing: Mobbing experienced by nurses working in healthcare facilities in Turkey and its effect on nurses. Journal of Clin Nursing, 16(8), 1445-1453.

Yıldız, S., Yıldız, S. E. \& Erdağı, S. (2009). Sağlık çalışanlarının yıldırıcı davranış davranışının değerlendirilmesi. Hastane Yönetimi Dergisi, 13(1), 1-13.

Yiğitbaş, Ç. \& Deveci, S. E. (2011). Sağlık çalışanlarına yönelik mobbing. Türk Tabipleri Birliği Mesleki Sağlık ve Güvenlik Dergisi, 42(11), 23-28. 